Boston University School of Law

Scholarly Commons at Boston University School of Law

Faculty Scholarship

8-2016

\title{
Reconsidering Realization-Based Accounting for Equity Compensation
}

David I. Walker

Boston University School of Law

Follow this and additional works at: https://scholarship.law.bu.edu/faculty_scholarship

Part of the Accounting Law Commons

\section{Recommended Citation}

David I. Walker, Reconsidering Realization-Based Accounting for Equity Compensation , in No. 16-03 Boston University School of Law, Law and Economics Research Paper Series (2016).

Available at: https://scholarship.law.bu.edu/faculty_scholarship/257

This Article is brought to you for free and open access by Scholarly Commons at Boston University School of Law. It has been accepted for inclusion in Faculty Scholarship by an authorized administrator of Scholarly Commons at Boston University School of Law. For more information, please contact lawlessa@bu.edu. 


\title{
BU School of Law
}

\section{RECONSIDERING REALIZATION-BASED ACCOUNTING FOR EQUITY COMPENSATION}

\author{
Boston University School of Law \\ Law \& Economics Working Paper No. 16-03
}

revised August 29, 2016

David I. Walker

Boston University School of Law

This paper can be downloaded without charge at:

http://www.bu.edu/law/faculty-scholarship/working-paper-series/ 


\title{
ReConsidering REALIZATION-BASED ACCOUNTING FOR Equity CoMPENSATION
}

\author{
David I. Walker*
}

\begin{abstract}
The U.S. equity compensation landscape continues to evolve. Recent innovations have improved the linkage between pay and firm-specific performance, but have added complexity. Against that backdrop, this Article urges reconsideration of the accounting rules for equity pay. Under current rules, most equity pay awards are expensed based on grant date valuation with no updating for changes in value post grant. This Article advocates the adoption of a mark-to-market or realization-based approach under which the expense recorded for all equity pay awards would ultimately be trued to the value received by employees. Increasingly, equity pay awards are more analogous to commissions than to arm's length investments, and the tighter link between pay and firm-specific performance suggests that including postgrant changes in equity pay award values in compensation expense tends to improve accuracy, not just add noise. In addition, increased complexity leads to greater ex ante valuation uncertainty and gaming opportunities, suggesting de-emphasizing reliance on ex ante measurement to the extent possible. Realization-based accounting also produces book/tax conformity for equity pay, which further combats gaming, and it levels the accounting playing field for equity instruments, minimizing accounting-induced distortions in pay design. The Article also argues that concerns that realization-based accounting will introduce an unacceptable level of uncertainty or volatility into compensation expense can be mitigated.
\end{abstract}

${ }^{*}$ Professor of Law and Maurice Poch Faculty Research Scholar, Boston University School of Law. Acknowledgments to follow. 


\section{TABLE OF CONTENTS}

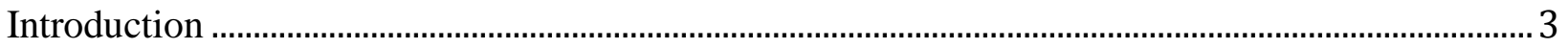

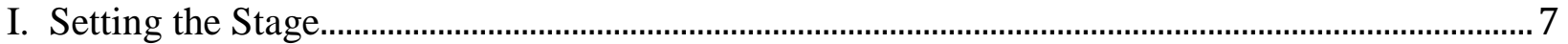

II. Equity Pay Vehicles and Accounting Treatments ….................................................................... 9

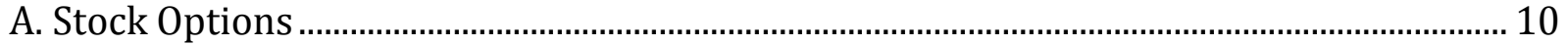

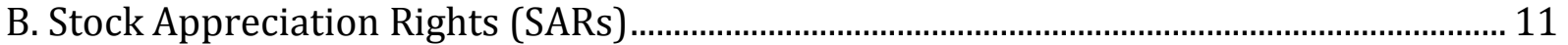

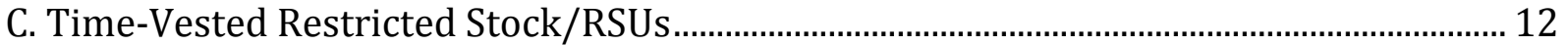

D. Performance-Based Restricted Stock/RSUs .......................................................................... 13

E. Other Equity-Based Compensation Instruments ….......................................................... 15

III. Designing an Optimal Accounting Approach for Equity-Based Pay ......................................... 15

A. The FASB's Approach to Accounting for Equity Pay............................................................ 16

B. A Reconsideration of the FASB's Position and Other Considerations Favoring Realization-Based Accounting..................................................................................................... 18



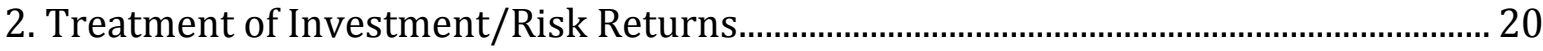

3. Valuation Uncertainty, Manipulation and Obfuscation.................................................... 26

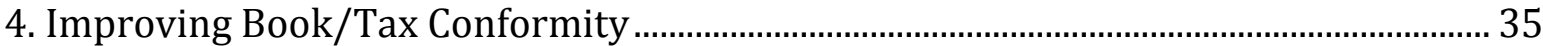

5. Avoiding Accounting Driven Design Choices ............................................................................. 36

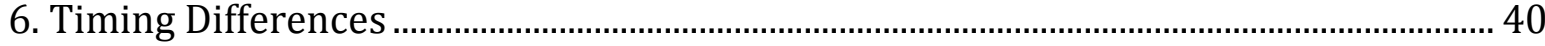

C. Additional Arguments Against Realization-Based Accounting for Equity Pay................. 42

1. Mark-to-Market or Realization-Based Accounting Introduces Unnecessary Noise into Reported Compensation Expense ................................................................................... 42

2. Realization-Based Accounting Creates an Unacceptable Level of Uncertainty in

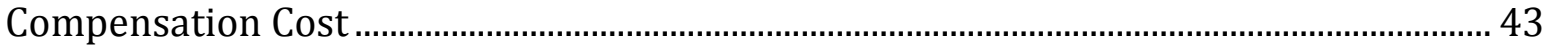

3. Realization-Based Accounting Creates an Unacceptable Level of Volatility in

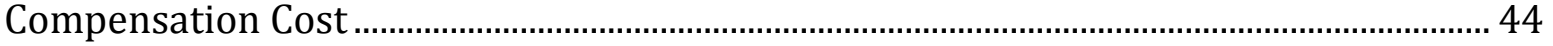

IV. A Note on Hedging Equity Compensation Awards ..................................................................... 46

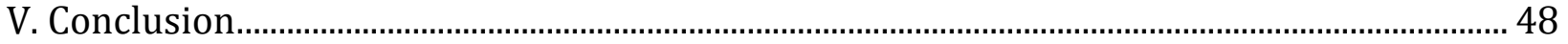




\section{Introduction}

Equity compensation accounting issues have vexed the profession since stock options emerged as a significant compensation tool in the 1970s and 1980s. Compensatory stock options dominated equity pay, and particularly executive equity pay packages, in the late 1990s and early 2000s. ${ }^{1}$ One reason for their popularity may have been that, prior to 2004, options were free goods from an accounting perspective. Firms were not required to record an expense for option compensation at any time. ${ }^{2}$

The Financial Accounting Standards Board (FASB) had long recognized that this treatment was inappropriate. The FASB issued an invitation to comment on stock option accounting in 1984, ${ }^{3}$ and issued an exposure draft in 1993 proposing that options be expensed. ${ }^{4}$ Expensing was fiercely resisted by industry, ${ }^{5}$ and Senator Lieberman introduced legislation to block FASB from requiring option expensing. ${ }^{6}$ The FASB backed off, requiring in 1995 only that option expense be footnoted in financial statements, not recorded as an adjustment in calculating net income. ${ }^{7}$ Finally, in 2004, after options-related scandals at Enron, WorldCom, Tyco

\footnotetext{
${ }^{1}$ Kevin J. Murphy, Executive Compensation: Where We Are, and How We Got There, in 2 HANDBOOK OF THE ECONOMICS OF FINANCE 226 (George M. Constantinides et al. eds., 2013); David I. Walker, Evolving Equity Compensation and the Limits of Optimal Contracting, 64 VAND. L. REV. 611, 633 (2011).

2 See Accounting Principles Bd., Opinion No. 25, Accounting For Stock IsSued to Employees (1972) [hereinafter APB 25]. Under APB 25, only the intrinsic value of an option at the date of grant - the degree to which an option was in the money at grant - was recognized as an expense. Almost all options were granted "at the money" with zero intrinsic value at grant, and as a result these options resulted in no expense. See also, Murphy, supra note 1, at 281 ("The accounting treatment of options promulgated the mistaken belief that options could be granted without any cost to the company.... Nonetheless, the idea that options were free (or at least cheap) was erroneously accepted in too many boardrooms").

${ }^{3}$ Fin. Accounting Standards BD., Invitation to Comment, Accounting for Compensation Plans InVOlVing CERTAin Rights GRANTED to EMPlOYEES (May 1984).

4 Fin. Accounting Standards BD., Exposure Draft, Accounting For Stock-based COMPENSATION (June 1993).

${ }^{5}$ Reportedly the FASB received over 1700 comment letters on the exposure draft, mostly opposing stock option expensing. RICHARD G. SCHROEDER, ET AL., FINANCIAL ACCOUNTING THEORY AND ANALYSIS 532 (11th ed. 2014).

${ }^{6}$ SCHROEDER ET AL., supra note 5, at 532. To be fair, Senator Levin had proposed legislation in January 1993 to compel the SEC to require companies to expense options issued to senior executives. Corporate Executives' Stock Option Accountability Act, S. 25, 103rd Congr. (1993). Obviously, this was a highly politicized debate.

7 Fin. Accounting Standards Bd., Statement of Fin. Accounting Standards No. 123, AcCOUnTING FOR STOCK-BASED COMPENSATION (Oct. 1995) [hereinafter SFAS No. 123].
} 
and elsewhere, the FASB had the political capital to mandate stock option expensing, and it did so. ${ }^{8}$

There was little consensus among those supporting stock option expensing as to exactly how firms should account for the cost of employee services paid for with non-transferable options. Some commentators advocated grant date measurement of option value utilizing a model. ${ }^{9}$ Grant date measurement had the advantages of determining compensation expense, once and for all, at grant, and of separating compensation cost from investment returns on options post grant. ${ }^{10}$ But there were concerns about applying models designed for market traded options to non-transferable employee options, 11 and other commentators argued for measurement of compensation cost at the point at which options were exercised or expired unexercised, at which time the ultimate cost to shareholders would be certain. ${ }^{12}$

In 2004, the FASB adopted grant-date measurement of option value. ${ }^{13}$ Perhaps a majority of the FASB believed this to be the most appropriate approach. ${ }^{14}$ Perhaps this was all they thought they could get. ${ }^{15}$ In any event, the 2004 option expensing requirement was a major step in the right direction. At the time, expensing options based on grant date valuation largely leveled the playing field between the two most significant forms of equity pay - options and restricted stock - as restricted stock had long been expensed based on grant date value. ${ }^{16}$

Fast forward to 2016. Equity pay flourishes, particularly in executive suites, but the landscape has shifted. Stock options are passé. ${ }^{17}$ The gap created by the declining use of options has been largely filled with performance-based restricted stock, aka performance shares. ${ }^{18}$ Performance share plans are highly heterogeneous and often quite complex. ${ }^{19}$ Moreover, some performance shares are

\footnotetext{
8 Fin. Accounting Standards Bd., Statement of Financial Accounting Standards No. 123 (revised 2004) [hereinafter SFAS 123R]. ${ }_{9}$ SFAS 123R, supra note 8, at B46-48, B60.

10 SFAS 123R, supra note 8 , at B47.

11 SFAS 123R, supra note 8, at B59.

12 SFAS 123R, supra note 8, at B45. These were not the only possibilities. Some respondents, for example, suggested that measurement occur at option vesting. Id. at B3536.

13 SFAS 123R, supra note 8, at B46-48.

14 The FASB said as much in SFAS 123R. See SFAS 123R at B46-48.

15 The FASB noted that an "overwhelming majority" of those providing comments who addressed the issue supported grant date measurement. SFAS 123R, supra note 8, at B48. ${ }^{16}$ APB 25, supra note 2 .

17 As noted infra note 39 and 48, in S\&P 500 company executive suites, options accounted for $60 \%$ of the aggregate ex ante value of total pay at their peak and now contribute only 16 to $17 \%$.

${ }^{18}$ Infra text accompanying note 63.

${ }^{19}$ Infra text accompanying note 64 .
} 
accounted for like options; others are subject to a very different accounting regime. ${ }^{20}$ The level playing field lasted less than a decade. Once again, accounting rules are likely to be influencing compensation plan design.

Given the substantial shift in the equity pay landscape, this article argues that it is time to reopen the question and reconsider the accounting treatment for equity pay - specifically whether FASB's apparent preference for grant date measurement remains appropriate (if it ever was), or whether we should shift to a realizationbased or "mark-to-market" approach.

This article will consider equity pay accounting primarily from a functional perspective, considering the needs of investors and the impact of accounting on corporate governance. ${ }^{21}$ From an investor's perspective, the optimal accounting regime would produce accurate and robust (i.e., not subject to manipulation) information on the cost of employee services and would facilitate comparison of employee costs from firm to firm and over time. Because accounting rules determine the senior executive pay information that public companies are required to disclose annually in their proxy statements under SEC regulations, ${ }^{22}$ accuracy and comparability are also governance concerns. Another concern from a governance perspective is that accounting for equity pay be neutral so as to avoid influencing corporate pay practices.

While certainly not free from doubt, this article will argue that the case for realization-based or mark-to-market accounting is stronger today than it has ever been before. There are three primary reasons for this.

First, under mark-to-market accounting, the ultimate compensation cost associated with equity-based pay is set equal to the realized gains enjoyed by the employees. $^{23}$ If one believes that share price movements between grant and realization are exogenous, including those movements in compensation cost introduces noise that undermines the usefulness of accounting information. But if one views those movements as endogenous, including those movements improves the accuracy of the accounting information. When time-vested restricted stock and stock options dominated long-term compensation packages, one could certainly argue that stock price movements post-grant were largely beyond the employees' control. In a rising market, all stocks and options tended to rise; and in a bear market, all stocks and options tended to fall. But the connection between firmspecific performance and equity compensation payouts is tightening. Many performance share grants, for example, produce payoffs that are based on a firm's

\footnotetext{
${ }^{20}$ Infra text accompanying notes 65-68.

${ }^{21}$ Put another way, I am not convinced that the classification of a stock-based pay award as representing the issuance of equity versus the creation of a liability should drive the accounting treatment. See infra Part III(B)(1).

22 Infra note 29.

23 Infra Part II(B).
} 
performance relative to the market or a particular peer group. Particularly when we consider compensation cost firm wide, there is a strong argument that realized gains on equity pay instruments represent a better measure of the cost of employee services than does a grant date measure of equity value, which assumes these gains are exogenous.

Second, grant date valuation of complex equity-pay instruments such as stock options and performance-based restricted stock requires the use of mathematical models. ${ }^{24}$ Company managers have discretion over the assumptions that are fed into these models and generate grant date "fair values." There is evidence that firms have selected assumptions to reduce the grant date value of options. ${ }^{25}$ Recently adopted equity pay instruments are even more complex than conventional options and the opportunities for manipulation of grant date value are likely to be greater than before. While manipulation can be reduced through regulation, one advantage of realization-based accounting is that the ultimate cost recognized is not based on a model. It is based on realized results. Thus, even if one views mark-to-market accounting as introducing noise into compensation cost measurement, there is a trade-off between manipulability and noise.

Third, the use of different accounting treatments for different equity pay instruments often results in accounting-driven equity pay design choices. ${ }^{26}$ The poster child for this effect was, of course, the pre-2004 accounting preference for stock options. While we have no such glaring inconsistency today, there are inconsistencies and undoubtedly accounting driven design choices. Given current limitations on modeling, we cannot value all equity pay instruments at grant. We also cannot apply what I will define and call partial mark-to-market accounting to all existing equity pay instruments. We can apply full realization-based or mark-tomarket accounting to all instruments. While doing so will not completely level the accounting playing field for these instruments, it will come closer to doing so than any of the alternatives.

The remainder of the paper is organized as follows. Part I sets the stage for the analysis that follows by describing the overall objective of the exercise, the uses of accounting information, and why accuracy and consistency matter. Part II describes the principal equity pay vehicles and the accounting rules applicable to them. While it's possible that completely new approaches could be developed, the existing approaches provide a healthy menu of alternatives for evaluation and analysis. Part III, the heart of the Article, provides that evaluation and analysis, outlining the various factors that one would consider in designing an optimal accounting scheme for equity pay and applying these to our real world pay instruments. The primary takeaway of Part III is that the case for realization-based accounting is strong. Given that, Part III goes on to consider various objections that

24 Infra Part III(A).

25 Infra text accompanying note 162.

${ }^{26}$ Infra Part III. 
could (and would) be made to mark-to-market accounting for all equity pay. After a brief discussion of equity pay hedging in Part IV, Part V concludes.

\section{Setting the Stage}

Before jumping into discussion of various equity pay instruments and accounting rules, we should begin with the big picture. What are we trying to accomplish with accounting for equity pay? What do we do with the information and why does it matter how we account for this compensation?

It is important to keep in mind that the overall goal is to recognize the cost of employee services that are performed in exchange for share-based compensation. ${ }^{27}$ Sometimes this cost may be capitalized, as when, for example, employee services are dedicated to the production of self-constructed fixed assets. ${ }^{28}$ Generally, however, the compensation cost will be immediately deducted, or "expensed," in determining corporate earnings. The primary use of compensation cost accounting is in determining earnings.

Accounting information is also used for proxy statement disclosure of the compensation of the "top five" executives of U.S. public companies. ${ }^{29}$ Although this use is undoubtedly secondary from an accountant's point of view, it is highly important from a corporate governance perspective. If one believes that either market forces or public shaming limit executive pay, 30 these disclosures are critical for either mechanism to have an effect.

27 Fin. Accounting Standards Bd., Accounting Standards Codification 718-10-10-1 [hereinafter ASC 718-10-10-1]. It is a subtle distinction, but we are not recognizing the cost of the equity compensation delivered to employees, but the cost of their services paid for with equity instruments.

28 PriceWaterhouseCoOpers, Guide to ACCOUNTING FOR STOCK-BASEd Compensation: A MULTIDISCIPLINARY APPROACH [hereinafter PWC] 1-84.

${ }^{29}$ Disclosure is required for the "named executive officers," a group which currently includes a company's CEO, CFO, and three most highly compensated executives other than these two individuals. 17 C.F.R. $\S 229.402(a)(3)$ (2015). Although the SEC's disclosure rules incorporate ASC 718 valuation methodology, several different disclosures are required, including a summary compensation table that details and aggregates the grant date value of executive pay provided in each year. See 17 C.F.R. § 229.402(a)(3) (2015) passim. Disclosure of grant date valuation is considered important as it provides information on the expected compensation agreed to by a board and facilitates crosscompany comparisons of executive pay. See Brian Cadman et al., Shareholders' Use of Proxy Statement Disclosures to Evaluate Executive Pay 2-3 (Working Paper, Oct. 2015).

30 These are shorthand designations for the optimal contracting and managerial power views of the executive compensation setting process, respectively. For an overview of the theory and evidence regarding corporate governance and public company executive pay see David I. Walker, The Law and Economics of Executive Compensation: Theory and Evidence, in 
Given these goals and uses, it is obvious that accounting rules should be designed to provide an accurate and consistent picture of compensation cost associated with equity pay from firm to firm and over time for particular firms. "Noisy" or inaccurate information on equity pay contributes to noisy or inaccurate earnings (assuming equity compensation represents a significant cost firm-wide) and undermines the disciplinary force of executive pay disclosures. Inconsistency in the accounting treatment of various equity pay instruments may lead to accountingdriven design choices.

Now at this point some readers may ask why accounting rules that have no impact on cash flows, such as a requirement to expense stock options, would create a distortion in firm behavior. Wouldn't market analysts see through management attempts to reduce reported compensation cost and increase earnings by loading up on option pay, in which case management would forego such futile efforts?

The extent to which accounting treatments have real economic consequences is unclear, but there are several reasons to think that accounting matters, even when differences in accounting treatments are seemingly cosmetic. ${ }^{31}$ First, as a theoretical matter, the positive accounting literature explains that in some cases reported earnings matter independently of cash flows because of various contractual provisions, such as debt covenants, that are tied to earnings. In a world of positive transactions costs, even cosmetic changes in earnings can impact shareholder value. ${ }^{32}$

Second, empirical evidence - both event study and survey evidence establishes that accounting standards and practices matter. ${ }^{33}$ Accounting choices vary systematically between firms; firms respond to changes in accounting rules, and firms sacrifice cash flows to boost reported earnings. Whether rational or not, managers act as if accounting rules matter, so they do matter.

Third, it seems particularly difficult to maintain an "accounting irrelevance" position in the realm of equity pay. Professor Kevin Murphy has argued that the favorable accounting treatment of compensatory stock options contributed to the their over-use in the late 1990s and early 2000s. ${ }^{34}$ Although other factors likely

RESEARCH HANDBOOK ON THE ECONOMICS OF CORPORATE LAW 232 (Claire Hill \& Brett McDonnell eds. 2012).

31 This point is well established in the accounting literature, but is sometimes resisted by non-accountants who subscribe to a relatively strong view of efficient markets.

32 See generally Ross L. WatTs \& Jerold L. Zimmerman, Positive Accounting Theory (1986); Ross L. Watts \& Jerold L. Zimmerman, Positive Accounting Theory: A Ten Year Perspective, 65 ACCT. REV. 131 (1990); see also David I. Walker, Financial Accounting and Corporate Behavior, 64 WASH. \& LEE L. REV. 927, 935-49 (2007).

33 See Walker, supra note 32, at 949-965 for an overview of this evidence.

34 Murphy, supra note 1 , at 279-82. 
played a role, ${ }^{35}$ the steep drop off in option use following FASB's decision in 2004 to require firms to expense the grant date fair value of options supports Murphy's argument. Moreover, as recounted in the introduction, firms fiercely resisted stock option expensing. Clearly, the managers of these firms believed expensing was an important issue. ${ }^{36}$

This article will assume that the accounting treatment of equity pay has realworld consequences. It will assume that significant disparities in treatments can produce distortions in pay packages; that earnings matter independent of cash flows; and that the efficacy of executive pay disclosures depends on the quality of the information disclosed, but that disclosure of accounting information in footnotes to financial statements is not a perfect substitute for incorporating that information in reported earnings. ${ }^{37}$

Equity pay raises two principal accounting issues: measurement or valuation and the timing of cost recognition. This article focuses primarily on the valuation or measurement issues. As we will see, recognition timing is largely determined by the choice of measurement technique, but is relatively consistent in any event. ${ }^{38}$ Moreover, from a corporate governance perspective, the timing of compensation cost recognition is less important than the determination of the amount of pay.

\section{Equity Pay Vehicles and Accounting Treatments}

\footnotetext{
35 Tax rules certainly played a role, as well. I.R.C. $\S 162(\mathrm{~m})$ enacted in 1993 limited corporate deductions for senior executive compensation to $\$ 1$ million per executive per year, but provided an exception for certain performance-based compensation. Conventional at-the-money stock options easily satisfied the exception. Thus, firms could provide senior executives with an unlimited amount of fully deductible compensation in the form of options. Brian J. Hall \& Jeffrey B. Liebman, The Taxation of Executive Compensation, in 14 TAX Pol'y \& ECON., 1-2 (James M. Poterba ed., NAT'L BuREAU OF ECON. RESEARCH 2000); Murphy, supra note 1, at 278; Gregg D. Polsky, Controlling Executive Compensation through the Tax Code, 64 WASH. \& LEE L. REV. 877, 917-20 (documenting the widespread belief among informed observers that $\S 162(\mathrm{~m})$ contributed to the options explosion, but also noting the lack of clear cut empirical evidence).

Murphy, supra note 1 (2013), at 275-288, discusses several other factors that may have contributed to the stock option explosion: investor pressure for equity pay, a change in SEC rules regarding SEA section 16 holding periods, disclosure rules, and stock exchange listing requirements.

36 Supra text accompanying note 5.

37 The stock option expensing saga strongly suggests that including information in footnotes to financial statements is not equivalent to recognition of an item as an expense on the income statement. Note that the fight in the late 1990s and early 2000 s was solely over elevating stock option expense from footnote to earnings statement adjustment.

${ }^{38}$ Infra Part III.B.6.
} 
The equity-pay landscape and corresponding accounting rules have evolved considerably over the last fifteen years. This Part briefly describes those pay practices and the accounting treatments, providing a context for the analysis that follows. This Part focuses on public companies, which are required to provide audited financial statements prepared in accordance with Generally Accepted Accounting Principles (GAAP), and chiefly on large public companies that make up the bulk of the U.S. stock market capitalization.

\section{A. Stock Options}

At the height of the stock option boom in 2000, options accounted for over $60 \%$ of the aggregate compensation (measured by ex ante value) of the senior executives of S\&P 500 companies. ${ }^{39}$ Many of these firms issued stock options to upper-, mid-, and lower-level managers and some to rank and file workers. ${ }^{40}$ Options were also ubiquitous at start up companies and remain so today. ${ }^{41}$

As recounted in the Introduction, prior to 2004, firms could avoid recording any expense for options issued at the money, but in that year the FASB promulgated rules requiring companies issuing options as compensation to determine a grant date "fair value" for these awards, and to recognize that expense ratably over the vesting period of the options. ${ }^{42}$ Compensatory options typically vest, or become exercisable, in tranches starting a year or so after grant and ending three or four years after grant. 43

\footnotetext{
39 Walker, supra note 1 , at 633.

40 Paul Oyer \& Scott Schaefer, Why Do Some Firms Give Stock Options to All Employees?: An Empirical Examination of Alternative Theories, 76 J. FIn. ECon. 99, 100 (2005). See also Brian J. Hall \& Kevin J. Murphy, The Trouble with Stock Options, 17 J. ECON. PERSP. 49, 51 (2003).

${ }^{41}$ Denise A. Jones \& Kimberly J. Smith, Employee Stock Options: A Standard Setting Saga, 8 J. Bus. Case STUd. 241, 242 (2012); Leaders: The Trouble with Stock Options, The EconomisT, Aug. 7, 1999, at 13-14 (noting that options have "reduced the cash costs of starting a company: employees can be brought on board with the mere promise of future growth that a share option presents"). See also Joseph Bankman, The Structure of Silicon Valley StartUps, 41 UCLA L. REV. 1737, 1750 (1994); David I. Walker, The Way We Pay Now: Understanding and Evaluating Performance-Based Executive Pay 1 n. 5 (Boston Univ. School of Law, Law \& Economics Working Paper No. 15-34, Oct. 2015).

42 See SFAS 123R, supra note 8.

43 Frederic W. CoOK \& Co., InC., The 2014 Top 250 Report: LonG-Term InCEnTIVE Grant PRACTICES FOR EXECUTIVES 11 (Oct. 2014) [hereinafter Cook (2014)] (reporting that 90\% of options granted by sample companies vested within three or four years of grant and that $81 \%$ of option grants vested in installments). Cook's sample includes the 250 largest companies in the S\&P 500 index.
} 
The grant date fair value of options is determined by using a model. ${ }^{44}$ The Black-Scholes-Merton (BSM) model is most familiar. ${ }^{45}$ In order to determine option value using BSM, one must input the current market price of the stock, the option exercise price (typically the market price at the time of grant), the stock's expected volatility, a risk-free interest rate, expected dividend yield, and expected time to exercise. ${ }^{46}$ Once an initial value is calculated, that value is used to determine the compensation expense throughout the option's life. It is not updated for subsequent stock price movements. ${ }^{47}$

Option use by large public companies has declined precipitously in recent years. In 2013, options accounted for only about $16-17 \%$ of aggregate senior executive pay at S\&P 500 companies. ${ }^{48}$

\section{B. Stock Appreciation Rights (SARs)}

SARs are essentially phantom stock options. Instead of having a right to purchase stock in the future at a predetermined exercise price, an employee holding an SAR has a right to be paid in cash (or stock) the difference between the market price of the stock at some future point and a pre-set price, analogous to the exercise price of an option. ${ }^{49}$ Economically, SARs and options are identical, but their

${ }^{44}$ Fin. Accounting Standards Bd., Accounting Standards Codification 718-10-55-11. The discussion that follows pertains to time-vested options that do not include performance conditions. Performance-vested options are rarely observed. See J. Carr Bettis, John Bizjak, Jeffrey Coles \& Swaminathan Kalpathy, Performance-Vesting Provisions in Executive Compensation 55 (Table 2, Panel A) (Working Paper, Mar. 25, 2016) [hereinafter BBCK (2016)] (reporting that only one firm in their sample of over 1000 companies issued performance-contingent options in 2012). A performance-contingent option would be accounted for in a fashion similar to that of performance shares. See infra Part II.D.

45 See John C. Hull, Options, Futures, AND OTher Derivatives $299-44$ (8 $8^{\text {th }}$ ed. 2012). Sometimes the model is simply referred to as the Black-Scholes model. Id. at 299.

46 HULL, supra note 45 , at 214.

${ }^{47}$ Fin. Accounting Standards BD., Accounting Standards Codification 718-10-30; PWC, supra note 28, at 1-13. The grant date fair value of the award is expensed ratably over the option vesting period. Fin. Accounting STANDARDS BD., Accounting STANDARDS Codification 718-10-35-2 [hereinafter ASC 718-10-35-2]. See also, PWC, supra note 28, at 1-24. Although option value is not re-measured to reflect market movements, the aggregate expense associated with options grants is adjusted to reflect likely forfeitures. ASC 718-1030-11.

48 The Wall StREET JouRnal/HAY GRoup, 2014 CEO CoMPENSATION STUDY 5 (2015) (reporting that options accounted for $16 \%$ of aggregate CEO pay at a sample of large firms in 2014). Execucomp data suggests that options accounted for about $17 \%$ of senior executive pay at S\&P 500 firms in 2013. Author's calculations.

${ }^{49}$ SARs may be stock settled or cash settled or may provide for settlement in stock or cash at the election of the company or the employee. Judith E. Alden \& Murray S. Akresh, Using Equity to Compensate Executives, in ExECUTIVE Compensation 67, 98 (Yale D. Tauber \& 
accounting treatment is very different. Cash-settled SARs are considered liabilities rather than equity instruments, and they are accounted for on a mark-to-market basis. ${ }^{50}$ A model is used to determine the value of a cash-settled SAR, and that value is reassessed periodically. ${ }^{51}$ Ultimately, the compensation cost recognized with respect to a cash-settled SAR is set equal to the employee's realized gain on exercise. ${ }^{52}$ As a result, the recognition period for SAR compensation can extend beyond vesting to exercise. ${ }^{53}$ SARs are relatively unpopular, constituting a small fraction of the "options" issued by U.S. companies. ${ }^{54}$

\section{Time-Vested Restricted Stock/RSUs}

As the term suggests, restricted stock is stock that is issued to an employee, but is restricted with respect to sale or hypothecation. In the late 1990s, timevested restricted stock accounted for about $10 \%$ of the aggregate compensation of S\&P 500 senior executives. 55 Typically, this stock vests, or becomes owned outright by the recipient, all at once or in tranches, between a year and four years after

Donald R. Levy eds., 2002). Accounting for stock-settled SARs is identical to option accounting. PWC, supra note 28, at 1-52. The focus here is on cash-settled SARs and all references to SARs will assume that they are of the cash-settled variety.

${ }^{50}$ Fin. Accounting Standards BD., Accounting Standards Codification 718-30-35; PWC, supra note 28, at 1-13. The FASB does not use the term "mark to market." ASC 718-30-35 specifies that the fair value of liabilities associated with equity pay is to be re-measured periodically through settlement. I believe "mark to market" captures the flavor of this approach, although more technically, the approach here might be termed "mark to model" since there is no market in SARs to observe. The "market" prices being observed - share price, interest rates, volatility, etc. - are inputs for a model that is used to re-measure fair value from time to time. Despite these technicalities, I will generally refer to this method as "mark to market."

51 Fin. Accounting Standards Bd., Accounting Standards Codification 718-30-35-2 [hereinafter ASC 718-30-35-2]; PWC, supra note 28, at 1-44.

52 ASC 718-30-35-2, supra note 44; PWC, supra note 28, at 1-44.

53 PWC, supra note 28, at 1-45.

${ }^{54}$ Execucomp data does not distinguish between conventional options and SARs, leaving only survey data to fill the gap. In a recent study, Hay Group noted that $6 \%$ of 290 sample firms reported making SAR grants to executives in 2012, although that figure could include both stock settled SARs, accounted for like conventional options, as well as cash-settled SARs. Hay Group, EXecutive Compensation 2013: Data, Trends AND Strategies 20 (2014). Less than 5\% (11 firms) of 250 companies participating in a Frederick W. Cook executive pay survey reported using SARs in their compensation programs in 2013. FREDERIC W. COOK \& Co., INC., THE 2013 Top 250 RepoRT 12-20 (2013).

55 Walker, supra note 1, at 633. 
grant. ${ }^{56}$ As with options, restricted stock is often issued to mid-level managers as well as to senior executives.

A popular variation is called a restricted stock unit (RSU). While restricted stock is actually issued at grant and returned if it fails to vest, an RSU is a promise to deliver stock in the future if vesting conditions are satisfied. ${ }^{57}$ Economically, the two instruments are virtually identical. ${ }^{58}$

For accounting purposes, time-vested restricted stock awards and RSUs are valued at grant at the market price of the stock at grant, despite the possibility that some shares will be forfeited if employees leave their firm's employment prior to vesting. ${ }^{59}$ However, the total expense associated with restricted stock and RSUs at a particular firm is reduced by the number of shares that the firm expects to be forfeited, and that retention adjustment is updated from time to time. ${ }^{60}$ As with options, RS/RSU expense is recognized ratably over the vesting period. ${ }^{61}$

Time-vested RS and RSUs accounted for about 16\% of aggregate senior executive pay at S\&P 500 firms in 2013.62 In other words, use of conventional options and time-vested RS/RSUs at these firms is currently about balanced.

\section{Performance-Based Restricted Stock/RSUs}

As compensatory option use has declined, the void has largely been filled by performance-based restricted stock, which in recent years has accounted for about $30 \%$ of the aggregate compensation of CEOs at S\&P 500 companies. ${ }^{63}$ Unlike grants of stock options and time-vested restricted stock, which are strikingly uniform in design, performance-based restricted stock and stock units are quite

\footnotetext{
56 Cook (2014), supra note 43 , at 10-11 (reporting that $91 \%$ of restricted stock granted by sample companies vested within three or four years of grant and that $54 \%$ of stock grants vested in installments).

${ }^{57}$ Hay Group, The EXECUTIVe Edition (Sept. 2013) (reporting that over time RSUs have largely displaced conventional time-vested restricted stock).

58 There can be differences in dividend and voting rights, but the incentives created by RS and RSUs are identical. HAY GROUP, supra note 57.

${ }^{59} \mathrm{PWC}$, supra note 28, at 1-13. If employees are not entitled to dividends on RS/RSUs during the vesting period, the grant date value is reduced by the expected dividends, discounted to present value. $I d$.

60 PWC, supra note 28, at 1-13.

61 ASC 718-10-35-2, supra note 47. See also PWC, supra note 28, at 1-24

62 The WALl STREET JouRnal/HAY GrouP, supra note 48, at 5 (2015) (reporting that restricted stock accounted for $16 \%$ of aggregate CEO pay at a sample of large firms in 2014).

63 The Wall StReEt JouRnal/Hay Group, supra note 48, at 5 (reporting that performance awards accounted for $32 \%$ of aggregate CEO pay at a sample of large firms in 2014, although that figure could include some cash-settled performance awards).
} 
heterogeneous. 64 The most common variant, called performance shares, are grants of stock (or stock units) that vest only if both time and other performance conditions are satisfied. ${ }^{65}$ These plans typically include a variable number of shares that may vest based on satisfaction of increasingly ambitious performance targets measured over a pre-set period, most commonly three years. ${ }^{66}$ Targets may include accounting measures of performance, such as earnings per share, or share-price related metrics, such as total shareholder return. ${ }^{67}$ And performance may be measured on an absolute basis or relative to the performance of a group of peer companies or a broad market index. 68

Performance share awards that include only stock price or market measures of performance, such as total shareholder return, either absolute or relative, are valued and accounted for using the same approach that is used for options. A grant date fair value is determined for these instruments using a model, generally a Monte Carlo simulation. ${ }^{69}$ The grant date fair value is then expensed over the period between award grant and settlement with no adjustment for changes in share price in the interim. ${ }^{70}$ The compensation expense is adjusted to reflect shares that are expected not to vest because of forfeitures due to failure to meet the retention requirement, but there is no adjustment solely because it later appears that performance targets will not be met. ${ }^{71}$

Apparently, the FASB has concluded that performance share awards utilizing other metrics (most commonly accounting-based measures of performance) cannot be adequately valued at grant. ${ }^{72}$ The FASB has adopted a method that it refers to as performance condition accounting for these instruments, ${ }^{73}$ and which I will

\footnotetext{
64 See Walker, supra note 41, at 14-25.

65 See Walker, supra note 41, at 14-25.

${ }^{66}$ See Walker, supra note 41 , at 14-25.

${ }^{67}$ See Walker, supra note 41, at 14-25. Although there are complicating factors, earnings per share (EPS) is essentially the net income available to common shareholders divided by the weighted average number of common shares outstanding during the relevant period. As such, it is an accounting measure of performance. SCHROEDER ET AL., supra note 6, at 197. Total shareholder return for a period is the sum of the change in the value of a firm's common shares and per share dividends paid over that period, normally expressed as a percentage of share value at the beginning of the relevant period. It is a market measure of performance. ZVI BODIE ET AL., INVESTMENTS 45 (5th ed. 2002).

68 See Walker, supra note 41, at 14-25.

${ }^{69}$ Fin. Accounting Standards Bd., Accounting Standards Codification 718-10-30-14 [hereinafter ASC 718-10-34]; 718-10-55-13 to 55-20. See also PWC, supra note 28, at 1-21, 6-2 to 6-37. Typically, these plans are too complex for application of the BSM methodology. ${ }^{70}$ ASC 718-10-30-14, supra note 69; ASC 718-10-35-2, supra note 47. See also PWC, supra note 28 , at $1-21,1-24$.

${ }^{71}$ ASC 718-10-30-14, supra note 69. See also PWC, supra note 28, at 1-21.

72 BBCK (2016), supra note 44, at $12 \mathrm{n} .11$.

73 Fin. ACCOUnTing STANDARdS BD., ACCOUnTing STANDARds Codification 718-10-20; ASC 71810-30-12, 13; PWC, supra note 28, at 1-21.
} 
sometimes refer to as partial mark-to-market accounting. For these instruments, firms are required to determine, at grant and periodically afterwards, the number of shares that is most probable to vest. ${ }^{74}$ The expense associated with these instruments is the grant date share price multiplied by the number of shares probable to vest. ${ }^{75}$ Over time, only the number of shares is adjusted for new information about the likelihood of retention or performance attainment; the share price is not updated; hence, partial mark to market. ${ }^{76}$

\section{E. Other Equity-Based Compensation Instruments}

We have now covered the most commonly used equity pay instruments, but less popular alternatives do exist. For example, some firms issue cash-settled performance awards that are analogous to the performance shares I have just described. ${ }^{77}$ These plans may or may not utilize share price or market metrics, such as total shareholder return. Like cash-settled SARs, these instruments are considered liabilities and their values are marked to market. The ultimate expense recognized for cash-settled performance awards is set equal to the value realized by the recipient.

For completeness, I should also note that many firms include equity pay in their annual incentive programs. These instruments raise no serious accounting challenges because of their short-term nature. The compensation cost associated with these instruments is simply the value realized by the recipient within the relevant period. ${ }^{78}$

\section{Designing an Optimal Accounting Approach for Equity-Based Pay}

\footnotetext{
${ }^{74}$ Fin. Accounting Standards Bd., Accounting Standards Codification 718-10-25-20; PWC, supra note 28, at 1-21. Outcomes are probable if "the future event(s) are likely to occur." ASC Topic 450. Where several future outcomes are possible, as in the case of performance share plans with variable numbers of shares potentially vesting, accounting accruals prior to vesting are based on the most probable outcome at any given measurement point.

75 Fin. Accounting STANDARds BD., Accounting Standards Codification 718-10-55-10 (defining the "fair value" of a restricted stock grant subject to a performance condition).

${ }^{76} \mathrm{~A}$ performance share award may contain both performance and market conditions, further complicating valuation and reporting. See Walker, supra note 41, at 36.

${ }^{77}$ HAY GROUP, supra note 54, at 21 (reporting that $16 \%$ of 300 firms studied made cashsettled performance awards in 2012 (versus 78\% issuing performance-based stock and 5\% issuing performance-based options).

${ }^{78}$ Susan Eichen \& Eric Scoones, Annual Incentive Plan Design Considerations, in Executive Compensation 35, 63 (Yale D. Tauber \& Donald R. Levy eds. 2002).
} 
As we have seen, the current equity pay landscape and accounting treatments are diverse, ranging from grant date fair value accounting (options, RS/RSUs, and some performance shares), to partial mark-to-market accounting (other performance shares), to full mark-to-market accounting (cash-settled SARs and performance awards). ${ }^{79}$ Compensation cost is generally recognized over the vesting period of the award, but the recognition period extends to exercise for SARs. While some diversity in accounting treatments may be inevitable given the diversity in instruments, diversity in accounting often leads to accounting-driven compensation design choices, which is suboptimal.

Is this variation unavoidable? More fundamentally, what would the optimal accounting regime for equity pay look like? This Part details the considerations that would feed into the design of an optimal approach. It considers both the FASB's priorities as well as "non-accounting" corporate governance factors. To some extent, this Part can be read as a critique of the FASB's current preference for accounting based on grant-date valuation.

\section{A. The FASB's Approach to Accounting for Equity Pay}

The FASB's overarching objective is to promulgate accounting standards that provide useful information to investors and creditors of reporting companies. ${ }^{80}$ That information should be relevant. It should faithfully represent the underlying economic phenomena, avoiding bias. The information should be comparable and consistent from firm to firm and across time. And it should be verifiable, understandable, and timely. ${ }^{81}$ But as Professor Stephan Penman has noted, demanding that financial statements reflect "economic reality" and be "true and fair" is only a starting point for the promulgation of rules and standards. ${ }^{82}$

In the specific case of equity pay, the objective is to recognize the cost to the entity of the services of the employees who receive the share-based pay instruments. ${ }^{83}$ This compensation cost is to be measured based on the "fair value"

\footnotetext{
${ }^{79}$ As noted supra note 50, the approach that I refer to as "mark to market" might more accurately be termed "mark to model." However, having adopted the "mark to market" term, I will now stop quibbling with myself.

80 Fin. ACCOUnTing STANDARDS BD., Conceptual Framework: Statement of Financial Accounting Concepts No. 8, Sept. 2010, at 1 [hereinafter SFAC 8]. See also SchroEDER ET AL., supra note 5, at 51-52.

81 SFAC 8, supra note 80, at 16. See also SCHROEDER ET AL., supra note 5, at 51-52.

82 Stephen H. Penman, The Quality of Financial Statements: Perspectives from the Recent Stock Market Bubble, 17 ACCT. HoRIZONS SuPP. 77, 79 (2003).

${ }^{83}$ ASC 718-10-10-1, supra note 27.
} 
of the instrument. ${ }^{84}$ Detailed guidelines are provided to assist companies in determining the fair value of various awards in various circumstances. ${ }^{85}$

These guidelines first distinguish between awards of equity instruments and awards that constitute liabilities. ${ }^{86}$ Grants that are settled with stock are generally treated as equity issuances, not as liabilities. Equity awards include stock options, RS/RSUs, and performance-based stock and option awards. ${ }^{87}$ Cash settled awards, such as SARs and cash-settled performance awards, are generally treated as liabilities. ${ }^{88}$ Awards treated as liabilities are accounted for on a mark-to-market basis, as described in Part II. ${ }^{89}$ Equity awards are expensed based on the "fair value" of the award. But as we saw in Part II, calculation of that fair value differs depending on whether the instrument is an option, RS/RSU, or performance share. ${ }^{90}$

I think it is fair to characterize the FASB's position as preferring grant date measurement/valuation of equity awards, when possible. ${ }^{91}$ In the 2004 statement that mandated expensing of stock options based on grant date valuation, the FASB discussed the pros and cons of the various alternatives, including mark-to-market accounting for these instruments. ${ }^{92}$ The statement noted several arguments advanced by advocates of mark-to-market accounting: that compensatory options should be considered liabilities, that mark-to-market or exercise date measurement is a better measure of compensation paid than grant date measurement, and that exercise date measurement is simple and straightforward, as contrasted with grant date valuation of options which requires application of complex mathematical models that were designed for tradeable options, not non-tradeable, nontransferable employee options. ${ }^{93}$

84 Fin. Accounting Standards Bd., Accounting Standards Codification 718-10-10-2 [hereinafter ASC 718-10-10-2]. It is important to distinguish the FASB's mandate that firms determine and expense the "fair value" of equity pay awards from the larger controversy within the profession concerning "fair value" accounting. The latter controversy has mainly to do with accounting for investments on a current "fair value" basis as opposed to an historical cost basis. This became a significant issue and a political issue during the 2008 financial crisis when market values of certain securities plummeted and were difficult to discern in thinly traded markets. See Schroeder ET AL., supra note 6, at 17 . In the case of equity pay awards, there is no historical cost basis to fall back upon, and each of the methods specified by FASB in ASC 718 are encompassed in the term "fair value based" accounting. ASC 718-10-10-2.

85 See generally Fin. Accounting Standards BD., Accounting Standards Codification 718.

86 SFAS 123R, supra note 8, at B117.

87 SFAS 123R, supra note 8, at B117.

88 SFAS 123R, supra note 8, at B117.

${ }^{89}$ Supra text accompanying note 50.

90 Supra text accompanying notes 44-47, 59-61, 69-71

91 This may not be the preference of the members in isolation, but may reflect the preferences of industry and political reality. See infra Part V.

92 SFAS 123R, supra note 8, at B34-48.

93 SFAS 123R, supra note 8, at B43-45. 
In mandating grant date measurement of stock option value, the FASB stressed that the instruments are better characterized as issuances of equity, not as liabilities; that the grant date is the date on which the employer and employee agree to the terms of the exchange, and presumably the parties base their agreement on the fair value of the instrument at that time; and that measuring compensation cost at a later date, such as at vesting or exercise, would include in compensation cost "both the value of the consideration exchanged for services and the return to the holder of the instrument from subsequent changes in its value."94 The FASB also noted that the overwhelming majority of those responding to the invitation to comment on the draft rules, and who responded on this particular point, preferred grant date measurement to the alternatives. ${ }^{95}$

There have been no relevant FASB promulgations since the 2004 statement that adopted grant date fair value accounting for stock options. Thus, there is no reason to think that the Board's position has changed. Moreover, the accounting rules for performance shares appear to reflect a similar preference for grant date valuation. For instruments for which model-based grant date valuation is feasible performance shares incorporating share price or stock market metrics - grant date measurement/valuation is mandated. Partial mark-to-market accounting applies to instruments that incorporate accounting metrics or other measures of performance that are not amenable to ex ante valuation. As in the case of options, if and when valuation techniques improve sufficiently to generate reliable ex ante measurement of the value of these instruments, presumably the FASB will mandate their use.

\section{B. A Reconsideration of the FASB's Position and Other Considerations Favoring Realization-Based Accounting}

It is not clear within FASB's own conceptual framework nor from a corporate governance perspective that FASB's emphasis on grant date measurement of equity pay instruments is appropriate. Moreover, the arguments favoring realizationbased accounting for equity pay would seem to be even stronger today than they were in 2004 when the FASB last publicly addressed the issue.

\section{Equity vs. Liability}

The distinction between firm equity and liabilities - the two components of the right hand side of the balance sheet - is fundamental to financial accounting, but the dividing line is actually contested. The FASB defines a liability as an obligation

94 SFAS 123R, supra note 8, at B46.

95 SFAS 123R, supra note 8, at B48. 
to transfer an asset. ${ }^{96}$ Cash is an asset, but common shares of a company are not assets; that's equity. Thus, a conventional option that entails an obligation to sell shares to an optionee is not a liability, but is the issuance of an equity instrument. ${ }^{97}$ On the other hand, an economically equivalent obligation that is to be settled in cash (a cash-settled SAR) is treated as a liability. ${ }^{98}$ The FASB's approach is consistent with the "entity" view of equity. ${ }^{99}$ Any issuance of shares to either pre-existing or potential new shareholders is equity. From the entity's perspective, it's all equity.

The alternative "proprietorship" view takes the perspective of the preexisting shareholders. ${ }^{100}$ From that perspective, the issuance of a conventional option is a liability - a liability of the pre-existing shareholders to issue new shares (or buy back shares) to deliver to the optionee on exercise. ${ }^{101}$

From a corporate governance perspective, of course, it is difficult to comprehend why the distinction between an instrument being characterized as an equity instrument versus as a liability should drive its accounting treatment. The accounting treatment aside, the equity/liability distinction has no impact on the choices that firms make with respect to compensation instruments. For example, stock options and cash-settled SARs are economically equivalent. Public companies should generally be indifferent between issuing options on actual shares and promising cash payments based on share price appreciation. ${ }^{102}$ But as a result of

96 Fin. Accounting Standards BD., Statement of Fin. Accounting Concepts No. 6, Dec. 1985, at 13 (amended 2008).

97 SFAS 123R, supra note 8, at B117.

98 SFAS 123R, supra note 8, at B117.

${ }^{99}$ See, e.g., James A. Ohlson \& Stephen H. Penman, Debt vs. Equity: Accounting for Claims Contingent on Firms' Common Stock Performance 27 (Ctr. for Excellence in Acct. and Security Analysis at Columbia Bus. Sch. White Paper No. 1, Jan. 2005).

100 See, e.g., Ohlson \& Penman, supra note 99, at 27. For more on the entity and proprietorship theories, see generally SCHROEDER ET AL., supra note 6, at 516-18.

${ }^{101}$ Consistent with the proprietorship perspective, Landsman, Pennell, Pope, and Yeh show as a theoretical matter that mark-to-market accounting for stock options best captures the economic impact on existing shareholders, and they provide empirical evidence supporting this view. Wayne R. Landsman et al., Which Approach to Accounting for Employee Stock Options Best Reflects Market Pricing?, 11 REv. Acct. STUdies 203, 208, 243 (2006).

102 In practice, the distinction between options and cash-settled SARs is even more insignificant than it would appear at first blush. Many companies that grant options provide for cashless exercise. Absent cashless exercise, an optionee is required to forward cash or previously owned shares equal to the exercise price to the company in order to exercise her option. With cashless exercise, a broker loans the optionee the exercise price and is repaid almost immediately with a portion of the proceeds of exercise. With cashless exercise, an optionee can fully convert option gains into cash (equivalent to a cash-settled SAR) or can convert just enough shares into cash to cover the exercise price and withholding taxes. Alden \& Akresh, supra note 49, at 173-74. Under FASB rules, cashless exercise of options does not trigger the mark-to-market accounting regime that is applicable to virtually identical cash-settled SARs. Fin. AcCOUnTING STANDARDS BD., ACCOUNTING STANDARDS CODIFICATION 718-10-25-16. 
the equity/liability distinction, options are valued at grant for accounting purposes, once and for all; SARs are marked to market.

The equity/liability distinction may be in flux. A minority of the Financial Accounting Standards Committee of the American Accounting Association favored treating stock options as liabilities in 1994 when the committee endorsed expensing options generally, ${ }^{103}$ and a number of commentators have continued to advocate for that position since. ${ }^{104}$ Moreover, the FASB has indicated that it intends to revisit the issue. ${ }^{105}$

Whether or not the broader issue ultimately is addressed by the FASB, it seems unwise to allow the equity/liability distinction to drive the accounting treatment of equity compensation. If liability treatment for all forms of equity pay is more appropriate and useful, given the various considerations explored below, then arguably an exception should be made if the current entity-focused framework is maintained. 106 Of course, consistency is important, but from a corporate governance perspective the accounting consistency that is most important is consistency between various pay instruments, not between the grant of options to employees and, say, the issuance of warrants to third parties. ${ }^{107}$

\section{Treatment of Investment/Risk Returns}

The key difference between grant date and mark-to-market accounting for equity compensation lies in the treatment of changes in value after the grant. Should we view as the opportunity cost to shareholders what an equivalent instrument could have been sold for at grant (excluding actual gains and losses

\footnotetext{
103 American Accounting Associations Fin. Accounting Standards Committee, Response to the FASB Exposure Draft "Accounting for Stock-Based Compensation," 8 ACCT. HoRIZONS 114, 114 (1994).

104 See, e.g., Steven Balsam, Extending the Method of Accounting for Stock Appreciation Rights to Employee Stock Options, 8 ACCT. HoRIzONS 52 (1994) (advocating application of SAR accounting to options); Michael Kirschenheiter et al., Accounting for Employee Stock Options, 18 ACCT. HoRIZONS 135 (2004) (advocating liability treatment for options); Penman, supra note 82, at 79-83 (advocating the proprietorship approach and treatment of options as liabilities); Ohlson \& Penman, supra note 99, at 29 (same); Letter of Comment No. 20 for Fair Acct. Standards Bd., Kenneth E. Stone \& Ronald D. Niemeyer, Accounting for StockBased Compensation 6 (Received Nov. 2002), available at http://www.fasb.org/cs/BlobServer?blobcol=urldata\&blobtable=MungoBlobs\&blobkey=id \&blobwhere=1175818119143\&blobheader=application\%2Fpdf (arguing that "nontransferable [options] are not in substance equity instruments").

105 Fin. Accounting Standards BD., Statement of Fin. Accounting Standards No. 150 (2003); see also Ohlson \& Penman, supra note 99, at 10-11.

106 Balsam, supra note 104, at 58 (taking a similar position with respect to options).

107 But see Ohlson \& Penman, supra note 99, at 1-2 (stressing the importance of applying a consistent approach to accounting for all performance contingent claims on a corporation, including employee options, warrants, convertible preferred stock, etc.).
} 
thereafter) or the actual cost incurred by the shareholders at settlement (including those fluctuations)? Commentators have argued both sides, but contributions to this debate are generally of a "self-evident" flavor. In rejecting post-grant revaluation of stock options, the FASB stated its view that it would be inappropriate to include the effects of changes in the value of an equity pay instrument in a firm's income statement, ${ }^{108}$ and that position is commonly encountered in the accounting literature. ${ }^{109}$ On the other hand, some more recent thinking on the subject supports including post-grant fluctuations in reporting the "total economic cost to the shareholders." 110 Each side seems to have a point. How are we to decide? This section will offer a principled basis for considering whether compensation cost should or should not include actual investment returns and will argue that, while not free of doubt, the case for including these returns (i.e., for mark-to-market accounting) is reasonably persuasive today.

Let us first be clear about how investment returns are dealt with under the various accounting regimes. Grant date values of stock options and performance shares with market conditions include expected investment returns. ${ }^{111}$ Grant date valuation is equivalent to the expected return discounted to present value. ${ }^{112}$ Although it isn't obvious, the current market price of a share of restricted stock or an RSU can also be thought of as including expected investment returns. In theory, the value of a share of stock is based on the discounted stream of cash flows the company is expected to generate. ${ }^{113}$ Full mark-to-market accounting, as applies currently to cash-settled SARs, results in actual investment returns being included in compensation cost. Partial mark-to-market accounting, as applies currently to performance share plans with accounting-based metrics, includes expected investment returns. Although the compensation cost associated with these instruments rises or falls depending on the number of shares that is probable to vest from time to time, share price movements do not factor into compensation cost measurement for these awards. The share price is fixed at grant.

\footnotetext{
108 SFAS 123R, supra note 8, at B47.

${ }^{109}$ See, e.g., Morton BACKer, Modern Accounting Theory 280 (Morton Backer ed. 1966) (stating that "any attempt to measure the compensation effected by the stock option ... must separate compensation from investment," which can only occur at grant).

110 Ohlson \& Penman, supra note 99, at 21 (emphasis in original). Similarly, Balsam, supra note 104, at 56, argues that under the SAR mark-to-market approach, the cumulative accounting expense reflects the opportunity cost to the firm. That's true; it reflects the opportunity cost at settlement, but the question remains whether the opportunity cost of the grant or settlement is the better measure of compensation cost. See also Penman, supra note 82, at 83 (arguing that inclusion of expected returns is inadequate); Landsman et al., supra note 101, at 243 (showing theoretically and empirically that mark-to-market accounting for stock options grants is most value relevant for existing shareholders).

111 Penman, supra note 82, at 83.

112 HULL, supra note 45, at 299.

113 Bodie et al., supra note 67, at 563.
} 
Is it more appropriate to base compensation cost on expected or actual investment returns? It depends. Consider two compensation schemes.

First, suppose an employee of Acme receives a salary of $\$ 100,000$ plus an opportunity to flip a coin at the end of the year. ${ }^{114}$ If heads, the employee receives an additional \$50,000; if tails, the employee receives no additional pay. Assuming a fair coin, the expected payoff is $\$ 25,000$, and the employee's total expected compensation for the year is $\$ 125,000$. In this situation, since the coin-flip result is exogenous, including expected returns $(\$ 25,000)$ but not actual returns (0 or $\$ 50,000$ ) in compensation cost more faithfully represents the underlying economics and promotes comparability and consistency. This compensation scheme is identical to one in which Acme pays the employee $\$ 125,000$ cash and the employee separately makes a $\$ 25,000$ bet on a coin flip. Including actual returns in compensation cost would only introduce noise that would make it harder to compare costs from firm to firm or over time given the randomness in the coin flip result.

Compare a compensation scheme in which a retail sales employee receives a salary of $\$ 10,000$ per year plus a $\$ 10$ commission for every sweater she sells. Suppose expected sales based on historical averages are 250 sweaters per year, yielding an expected commission of $\$ 2,500$. In this situation, it is more appropriate to include the actual commission paid in compensation cost, not the expected commission of $\$ 2,500$. The commission result is at least partially endogenous. It reflects, in part, the skill and effort of the employee. ${ }^{115}$ Unlike the coin-flip bonus, one cannot separate the commission from the compensation. Including actual results does not increase noise; it increases accuracy of compensation cost measurement. And GAAP reflects this commonsensical result, requiring actual commissions paid to be included in compensation cost. 116

So is equity compensation more like a coin flip or a sales commission? Are actual returns on equity pay instruments endogenous or exogenous? Well, some of both, but actual returns are increasingly endogenous. And when we consider that the objective is to calculate compensation cost firm wide, there is a strong argument for including actual returns in compensation cost.

This was less true ten to fifteen years ago when conventional stock options and RS/RSUs dominated long-term equity pay. Of course, even in that situation there was some endogeneity. If equity pay was used widely within the firm and if we take the incentives created by equity pay seriously, conventional option payoffs reflect, to some degree, the effort and skill of the employees, and inclusion of actual

\footnotetext{
114 I thank Gregg Polsky for pushing the coin-flip perspective.

115 It is also partially exogenous. No matter how skillful and persuasive the clerk, she will not be able to overcome a particularly unattractive line of sweaters.

${ }_{116}$ Put differently, nothing in GAAP requires or permits retail sales commissions to be expensed at any amount other than the amount actually paid.
} 
results in compensation cost increases accuracy, just as with sales commissions. ${ }^{117}$ The problem is that the link between pay and performance was so tenuous. The payoff associated with non-indexed stock and option grants often reflects overall market movements as much or more than firm-specific performance. ${ }^{118}$

But consider a firm that adopts a relative total shareholder return plan and makes awards widely through the executive and managerial ranks. The number of shares that are ultimately issued under these plans is a function of the firm's stock price (and dividend) performance relative to a broad market index or a peer group. So the noise of market movements is reduced, and payouts are tied more closely to firm-specific performance within the employees' control.119 of course, individual employees, even in the executive suite, have limited impact on that performance, but, again, the goal is to measure firm-wide compensation cost. On a firm-wide basis, a compensation cost measure that includes actual returns generated by a relative total shareholder return plan is arguably superior to one based on expected returns. 120

The FASB voiced another, related argument for adopting grant-date fair value accounting for stock options and other equity pay grants and rejecting markto-market accounting: "In deciding whether and on what terms to exchange equity instruments for employee services, both parties to the agreement presumably base their decisions on the current fair value of the instrument to be exchanged-not its possible value at a future date." 121 Setting aside the fact that, with the exception of the CEO and perhaps a handful of senior executives, equity pay grants are generally made unilaterally, this statement again reflects a mindset in which returns are exogenous. If an award's payoff is tied to the S\&P 500 or coin flips, the assumption

117 See Robert S. Kaplan \& Krishna G. Palepu, Expensing Stock Options: A Fair-Value Approach, HARV. BuS. REV. 105, 107 (Dec. 2003) (describing as the "chief characteristic of stock option compensation" that "employees are receiving part of their compensation in the form of a contingent claim on the value they are helping to produce"); Stone \& Niemeyer, supra note 104, at 7 (options "are analogous to offering a profit-based bonus as part of a compensation plan").

118 See, e.g., Alfred Rappaport, New Thinking on How to Link Executive Pay with Performance, HARV. BuS. REV. 91, 92 (Mar./Apr. 1999) (noting that "for the ten-year period ending in 1997, total return to shareholders-dividends plus increases in the share price-was positive for each of the 100 largest U.S. companies").

119 Under a typical relative total shareholder return (TSR) plan, the number of shares issued is a function of relative TSR. The value of these shares, however, is partially a function of market movements. So relative TSR plans tighten the relationship between pay and firmspecific performance, but do not completely insulate pay from market movements. See Walker, supra note 41.

120 This feature is not unique to relative TSR plans. Performance shares incorporating accounting or other non-market metrics such as safety performance also seem to be more akin to commissions than are conventional option and stock grants. The use of multiple metrics may further tighten the link between employee performance, outcomes, and pay.

121 SFAS 123R, supra note 8, at B46. 
that both parties focus on grant date valuation would be reasonable. Perhaps it is also a fair assumption with respect to individual rank and file employees receiving company stock or options. But would a senior company executive base her decisions on equity pay on the current fair market value or on her expectation of value at payout? These folks are not known for their humility. More germanely, would a compensation committee that adopted a firm-wide equity pay plan assume that the share price going forward was just a random walk? If so, what was the point to granting these equity incentives?

One sometimes hears the related argument that grant date valuation of equity pay instruments is appropriate because this is a measure of the firm's opportunity cost. ${ }^{122}$ One response to this argument is that firms never sell the types of equity instruments they issue to their employees. ${ }^{123}$ A better response, however, is similar to the argument in the preceding paragraph. If a firm sold instruments to third parties with a payoff linked to total shareholder return, it would not expect those instruments to have an impact on employee incentives and firm performance. It is the fact that these instruments are granted to individuals who have the collective ability to improve firm performance that matters. That makes the payoffs endogenous, and that bolsters the case for ex post evaluation of compensation cost.

To be sure, today's equity pay landscape is diverse. Conventional options haven't disappeared. Performance share plans, including relative total shareholder return plans are ascendant, but not dominant the way options were in the late 1990s. ${ }^{124}$ The argument is simply that, in aggregate, shifts in compensation practices improve the case for including actual returns in compensation cost, i.e., marking to market. But I certainly do not mean to suggest that we make this decision firm-by-firm or instrument-by-instrument. The goal is to avoid accountingdriven design decisions, not promote them. I will have more to say about this point in Part III.B.4 below.

But before we leave the topic of actual versus expected returns, there is a final point we should consider for completeness. Tying compensation expense to realized equity pay gains may serve an earnings-smoothing function. ${ }^{125}$ This is most obviously the case when a performance share plan utilizes earnings per share,

122 See, e.g., Jennifer Saiz, Expensing the Cost of Executive Option Schemes: Case Studies in the Australian Healthcare Industry, J.L. \& FIn. MgmT. (2003) ("Given that companies can issue warrants in the market and receive the fair value of those warrants in the form of income, there is an opportunity cost associated with the granting of stock options to employees.").

${ }^{123}$ Compensatory stock options are uniformly nontransferable and may not be immediately exercised, unlike market-traded options. HuLL, supra note 45, at 333.

${ }^{124}$ Supra text accompanying notes $1,34$.

125 Kirschenheiter et al., supra note 104, at 154. 
EBITDA, ${ }^{126}$ or another earnings-related measure, as a metric. Strong earnings performance over the performance period will result in the issuance of a large number of shares and high realized compensation cost; poor performance results in few or no shares being issued and low realized compensation. Marking the performance shares to market includes these swings in the final measure of compensation expense and tends to smooth earnings relative to accounting for these shares based on a fixed, grant date valuation. ${ }^{127}$

While this earnings-smoothing function is most obvious when equity payouts are based on earnings, it can occur with any plan under which the payouts are correlated with earnings. Since share price is correlated with earnings, even conventional stock options and RS/RSUs could serve this function to some degree. Generally, corporate finance professionals prefer smooth to variable earnings, all else being equal. ${ }^{128}$ Given that, one might think that firms would prefer SARs, which are marked to market, over conventional stock options, which are valued once and for all at grant. They do not. The clear preference is for actual options. There is no tax difference, ${ }^{129}$ so it is likely that the explanation has to do with accounting. One possibility is that the earnings-smoothing benefit is small or does not exist, or is relatively unimportant to management. Another might be that the flip side of the earnings-smoothing benefit is that compensation cost under a mark-to-market scheme is unpredictable. ${ }^{130}$ The perceived cost of compensation expense uncertainty may outweigh the earnings-smoothing benefits.

${ }^{126}$ An acronym for "earnings before interest, taxes, depreciation, and amortization." This is an important measure of earnings often used in debt covenants and incentive pay arrangements. See SCHROEDER ET AL., supra note 5, at 477.

${ }^{127}$ In Accounting Standards Update No. 2016-09, "Improvements to Employee Share-Based Payment Accounting" (March 30, 2016), the FASB revised the accounting rules applicable to employer tax deductions for equity pay. Formerly, earnings reflected only expected tax deductions for equity compensation. Under the new rules, employers must adjust earnings for the difference between actual tax deductions and expected deductions. This change will generally result in increased earnings volatility. See Nancy Nichols et al., Consequences of New Employee Share-Based Payment Rules, 152 TAX Notes 851 (Aug. 8, 2016).

While realization-based accounting for compensation cost arising from equity pay should generally reduce earnings volatility, Kirschenheiter, Mathur, and Thomas point out (Kirschenheiter et al., supra note 104, at 154) that mark-to-market accounting for equity pay can increase earnings volatility if equity pay adjustments are concentrated in a single year and larger earnings impacts are spread over several years. See infra text accompanying note 219 for further discussion of this potential problem as well as a possible solution.

128 See John R. Graham et al., Value Destruction and Financial Reporting Decisions, 62(6) FIN. ANALYSTS J. 27, 33 (2006) (97\% of CFOs responding to a survey reported preferring a smooth earnings path to a bumpy one and $78 \%$ indicated a willingness to sacrifice value to achieve smooth earnings).

129 Myron S. Scholes et AL., TAXes And Business Strategy: A Planning ApProACh 202 (2nd ed. 2002).

130 While compensation cost is certainly less predictable if equity pay instruments are marked to market, concerns that a short-term market swing could result in a single year 


\section{Valuation Uncertainty, Manipulation and Obfuscation}

It has always been a challenge to generate accurate and verifiable ex ante values for equity pay instruments, ${ }^{131}$ and that challenge has increased considerably with the shift away from conventional options in favor of more complex performance share plans. ${ }^{132}$ There is greater uncertainty regarding the tools of valuation and their application. Disclosure is less effective. And firms have greater opportunities to select favorable modeling assumptions that minimize reported compensation cost, which I will refer to as manipulation. ${ }^{133}$ Of course, valuation technology and reporting regulation may catch up with the evolution in pay instruments, but at the moment these difficulties suggest minimizing our reliance on ex ante valuation. To some extent, the FASB has done so in applying partial markto-market accounting to performance shares incorporating accounting-based metrics. But these realities strengthen the case for adopting full mark-to-market accounting for equity pay generally. This is not to suggest that adoption of performance share plans is a mistake for corporate governance. The pros may outweigh the cons. I am inclined to think that they do. ${ }^{134}$ But we should not ignore the impact of increased complexity on accounting for equity pay.

\section{a. Ex Ante Valuation}

The FASB has acknowledged that ex ante valuation difficulties might supply an argument for realization-based accounting, although to my knowledge the Board has never directly addressed the manipulation question. In adopting grant date fair value accounting for options in 2004, the FASB noted the arguments of mark-tomarket advocates that

[c]oncerns about how to apply option-pricing models initially developed for traded options to forfeitable, nontransferable employee options are much less significant if final measurement is based on the intrinsic value, if any, that an employee realizes by exercising an option. The usual accounting response to a major problem in measuring the effects of a transaction is to defer final measurement until the measurement difficulties are resolved. Exercise date

spike in compensation cost can be allayed. As discussed infra Part III(B)(2), several commentators have proposed an approach that would true final compensation cost to realized results, but that would smooth the impact on earnings across several periods. Note that this is not the same thing as basing compensation cost on a grant date calculation of fair value as firms do today.

131 See infra Part IV.

132 BBCK (2016), supra note 44, at 3.

133 Walker, supra note 41 , at 3.

134 Walker, supra note 41 , at 3. 
measurement might be appropriate for that reason regardless of more conceptual considerations. ${ }^{135}$

Concerns about applying the Black-Scholes-Merton (BSM) option pricing model and other models designed for traded options to compensatory options were, and to some degree remain, legitimate. These models were designed for relatively short-term traded options. The models are not perfect in that service, but their imperfections are magnified when applied to long-dated employee options. ${ }^{136} \mathrm{~A}$ more general concern was that BSM was designed for European options that are exercisable on a specific date in the future, whereas compensatory options are exercisable over a range of dates between vesting and expiration. ${ }^{137}$ While the difference would be relatively unimportant for a traded option, which should be held by someone until just before expiration, 138 employees holding compensatory options generally exercise them much earlier due to risk aversion or liquidity concerns. ${ }^{139}$ If her options were tradable, an employee seeking liquidity would sell to a third party and capture part of the remaining option value, but compensatory options cannot be sold and thus are generally exercised early. While not a perfectly satisfactory fix, ${ }^{140}$ the BSM model was modified to include the expected holding

135 SFAS 123R, supra note 8, at B45.

${ }^{136}$ See, e.g., Charles W. Calomiris, Expensing Employee Stock Options 38 (AEI Economic Policy Working Paper Series, Aug. 5, 2005), (suggesting that valuation errors may exceed $20 \%$ in $10 \%$ of the cases); Carol A. Marquardt, The Cost of Employee Stock Option Grants: An Empirical Assessment, 40 J. ACCT. RES. 1191, 1214 (2002) (finding that while an adjusted Black-Scholes model provided reasonable estimates of ex post option cost, on average, there was "significant variability in the amount of model error on an option-by-option basis").

137 Mark Rubinstein, On the Accounting Valuation of Employee Stock Options, 3 J. DERIVATIVES 8 (1995). Binomial models can explicitly incorporate the exercise date discretion afforded holders of American-style options, such as employee stock options. Id.

${ }^{138}$ At any given time, the value of an option consists of the current intrinsic value (the gain that can be achieved if the option were exercised at that point) and some remaining time value (arising from the possibility that the option will increase in value prior to expiration). Since the total option value exceeds intrinsic value prior to expiration, market traded options should not be exercised before that date. This simplified explanation ignores dividend payments, which can complicate the analysis. HuLL, supra note 45, at 225-26.

139 See J. Carr Bettis et al., Exercise Behavior, Valuation, and the Incentive Effects of Employee Stock Options, 76 J. FIN. ECON. 445, 446 (2005) (finding for a sample of 140,000 option exercises by executives at almost 4000 firms between 1996 and 2002 that, on average, options were exercised a little over two years following vesting and more than four years prior to expiration); Jennifer N. Carpenter, The Exercise and Valuation of Executive Stock Options, 48 J. FIN ECON. 127, 138-39 (1998) (finding for a sample of forty firms (mainly large manufacturers) that executive stock options granted between 1983 and 1984 were, on average, exercised after 5.8 years); Steven Huddart \& Mark Lang, Employee Stock Option Exercises: An Empirical Analysis, 21 J. ACCT. \& ECON. 5, 20 (1996) (finding that the median fraction of option life elapsed at the time of exercise ranged from 0.21 to 0.38 for options granted by seven public companies to a wide range of employees).

140 Some researchers have found that the adjustments to the pricing models made to reflect non-transferability can lead to overvaluation. See Thomas Hemmer et al., Estimating the 
period for a compensatory option, based on experience at a particular company, instead of the time to expiration, in order to generate a more realistic ex ante option value. ${ }^{141}$

Today, it is fair to say that most analysts are comfortable that the modified BSM and other approved valuation approaches provide reasonable estimates of the ex ante cost of compensatory stock options. ${ }^{142}$ But complex performance share plans are another matter. As Professors Bettis, Bizjak, Coles, and Kalpathy (BBCK) suggest, valuation is "significantly more problematic ... once the grant relies on a complex vesting provision based on one or more ... accounting, stock-price, sales, market-share, or other metric[s]."143 And in concluding their exhaustive empirical analysis of performance-vested equity pay plans, BBCK summarize the impact: "one consequence of the complexity associated with [performance-vesting] provisions is significant error in measurement of the [value and other characteristics] of executive compensation." 144

To provide a sense of the complexity without getting too deeply into the morass, let us compare ex ante valuation of a conventional stock option to that of a grant under a relative total shareholder return plan. Chevron, for example, issues both forms of equity pay to its senior executives. In its 2015 proxy statement and 2014 annual report, Chevron reported that its CEO received an option in 2014 on 344,000 shares. ${ }^{145}$ The company reported that the stock price at grant and the exercise price were $\$ 116 /$ share, the expected time to exercise was six years, the expected stock price volatility was $30.3 \%$, the risk-free interest rate was $1.9 \%$, and

"Fair Value" of Employee Stock Options with Expected Early Exercise, 8 ACCT. HoRIzons 23, 2738 (1994); Phelim Boyle \& William R. Scott, Executive Stock Options and Concavity of the Option Price, 13 J. DERIVATIVES 72, $72-77$ (2006).

${ }_{141}$ SFAS 123R, supra note 8, at A26-A30; see also Rubinstein, supra note 137.

142 See, e.g., BBCK (2016), supra note 44, at 3 ("It is not particularly difficult to value simple time-vested stock and options, or even primitive [performance-vested equity awards] ..."). Nondiversified employees receiving nontransferable options will place a lower value on the instruments than would a diversified third party, and thus option pricing models may not reflect the value perceived by the employee recipient. See, e.g., Zvi Bodie et al., For the Last Time: Stock Options are an Expense, HARV. BuS. REV. 63, 67 (March 2003) (reporting estimates of perceived employee discounts of $20 \%$ to $50 \%$ ). But this is a separate governance issue that does not bear directly on the appropriate accounting for compensation cost. If Acme pays its employee with a Mercedes that is worth $\$ 100,000$, $\$ 100,000$ is an accurate measure of compensation cost even if the employee only values the car at $\$ 75,000$. As Bodie, Kaplan, and Merton explain, "[f]inancial statements reflect the economic perspective of the company, not the entities (including employees) with which it transacts." Id. at 67.

143 BBCK (2016), supra note 44, at 3.

${ }^{144}$ BBCK (2016), supra note 44, at 44.

145 Chevron, 2015 Proxy Statement (Form DEF 14A) 46 (Apr. 9, 2015). 
the expected dividend yield was 3.3\%.146 Chevron reported a grant date fair value for this award of $\$ 8,586,240 .{ }^{147}$ I plugged these assumptions into a free online option pricing calculator and got a value of $\$ 8,517,440$, a difference of less than $1 \% .^{148}$

Chevron also reported that its CEO received a performance share award based on its total shareholder return relative to that of its peer group. After three years, the CEO will receive between zero and 100,000 shares depending on its total shareholder return rank. 149 The company reported a grant date fair value for this award of $\$ 4,816,500,150$ derived as follows:

We use a Monte Carlo approach to calculate estimated grant date fair value. To derive estimated grant date fair value per share, this valuation technique simulates total shareholder return (TSR) for the Company and for our [peer group] (BP, ExxonMobil, Royal Dutch Shell, and Total) using market data for a period equal to the term of the performance period, correlates the simulated returns within the peer group to estimate a probably payout value, and discounts the probable payout value using a risk-free rate for Treasury bonds... ${ }^{151}$

Of course, this is terribly obscure and impossible for an analyst to replicate, at least this analyst. But the problem is not simply inadequate disclosure, although that may also be a problem. These instruments are simply more complex than conventional options.

Sticking with relative total shareholder return plans, Radford, a compensation consultant, has published a short guide to valuation, which highlights the complexity. ${ }^{152}$ In addition to making assumptions regarding expected volatility, interest rates, and expected dividend yields, the analyst valuing a grant under one of these plans must also include data on the correlation between the share prices of the firm and the peer group of companies. ${ }^{153}$ There are several approaches for generating these correlation coefficients, and the choice of the approach, as well as the inputs, can affect the resulting valuation. ${ }^{154}$

146 Chevron, supra note 145, at 46 (Apr. 9, 2015) (strike price); Chevron, 2014 AnnuAL REPORT (Form 10-K) 59 (Feb. 20, 2015) (valuation assumptions).

147 CHEVRon, supra note 145, at 46 (Apr. 9, 2015).

148 Option Calculator, http://www.option-price.com/index.php (last visited Aug. 15, 2016).

149 CHEVRon, supra note 145, at 38, 40.

150 CHEVRON, supra note 145, at 46.

151 CHEVRON, supra note 145, at 45.

152 RadFord, RElative Total Shareholder REturn Plans: VAluation 101 (undated), available at

https://www.radford.com/home/press_room/pdf/Radford_alert_RelativeTSR_09232009.p df.

153 RADFORD, supra note 152.

154 RADFORD, supra note 152. 
Unfortunately, it gets worse. The FASB has essentially conceded that we currently lack the tools to generate adequate ex ante values for performance share awards that incorporate accounting-based metrics, such as earnings per share, or other non-share price metrics, such as safety performance. 155 As discussed above, when these metrics are employed, firms are directed to use a partial mark-tomarket approach under which the share price is set at grant, once and for all, but the number of shares that is probable to vest is initially estimated, re-determined periodically, and ultimately set equal to the number of shares that actually vest, if any. 156

The bottom line is that the shift towards performance shares represents a step backward for accurate ex ante valuation of equity pay and strengthens the argument for realization-based accounting.

\section{b. Manipulation and Obfuscation}

Setting aside simple time-vested RS/RSUs, which are largely manipulationproof under any accounting approach, each accounting approach involves some opportunity for valuation manipulation. The primary difference between grant date "fair value" accounting and partial mark-to-market accounting, on the one hand, and full mark-to-market accounting, on the other, is that the ultimate reported compensation expense under full mark-to-market accounting is much less manipulable. 157 Meanwhile valuation has become more obscure and the opportunities to select favorable valuation assumptions greater with the rise of performance shares, again bolstering the case for full mark-to-market or realizationbased accounting.

Recall that conventional options and performance share plans utilizing stock price or market metrics are currently valued at grant using an appropriate model. 158 The value derived determines both the grant date measure of compensation expense (important for proxy statement disclosures of executive pay) and the ultimate expense that is booked for employee compensation associated with the equity instrument. 159 There is no subsequent adjustment for stock price movements or changes in performance metrics. The only adjustment is a minor one reflecting the expected and actual number of shares that fail to vest because of

\footnotetext{
155 BBCK (2016), supra note 44, at 12 n.11.

156 Supra text accompanying notes 72-76

157 Of course, an employee could manipulate a firm's stock price at exercise or settlement, which would impact realized compensation and reported compensation expense. But because compensation cost is trued to employee realizations, the opportunity to manipulate valuation, independent of manipulating actions or disclosures, is largely eliminated with mark to market accounting.

158 Supra Part II.A, D.

159 Supra Part II.A, D.
} 
employee terminations. ${ }^{160}$ Put crassly, firms have two reasons to cheat when grant date valuation applies throughout - to minimize reported grant date executive pay and to minimize reported firm-wide compensation cost.

By comparison, when mark-to-market accounting applies, as with cashsettled SARs and performance plans currently, firms have only one reason to cheat to minimize reported grant date executive pay. Firm wide compensation cost will be trued up to match the realized payouts enjoyed by the employees.

As discussed, in the case of conventional stock options or SARs, grant date valuation requires the issuer to make assumptions regarding the stock's expected volatility, interest rates, expected dividend yields, and expected time to exercise. ${ }^{161}$ Discretion is required in selecting appropriate assumptions, and not surprisingly, firms tend to use this discretion to reduce the reported grant date "fair value" of options. 162

160 Supra note 47.
161 Supra text accompanying note 46.
162 See Eli Bartov et al., Managerial Discretion and the Economic Determinants of the
Disclosed Volatility Parameter for Valuing ESOs, 12 REV. ACCT. STUD. 155, 158 (2007) (finding
in a sample of over 9000 firm-years from 1998 to 2004 that firms opportunistically selected
volatility measures to reduce reported compensation); Preeti Choudhary, Evidence on
Differences Between Recognition and Disclosure: A Comparison of Inputs to Estimate Fair
Values of Employee Stock Options, 51 J. ACCT. \& Econ. 77, 91 (2011) (finding that
opportunistic selection of volatility assumptions to minimize option value and
compensation cost increased after stock option expensing was mandated in 2004); Leslie
David Hodder et al., Using Valuation Model Inputs to Manage Employee Stock Option
Disclosures 3 (Working Paper, Apr. 2004), available at http://www.ibrarian.net/navon/paper/Using_Valuation_Model_Inputs_to_Manage_Employ ee_S.pdf?paperid=1202774 (finding use of discretion to reduce pro forma earnings among a subset of firms); but see Steven Balsam et al., Managing Pro Forma Stock Option Expense under SFAS No. 123, 17 ACCT. HORIZONS 31 (2003) (finding little evidence of manipulation of overall option expense but finding manipulation of allocation of expense to minimize the first year impact). See also, Steven Balsam et al., Frontline Reaction to FASB 123(R), $203 \mathrm{~J}$. ACCOUNTANCY 54, 55 (2007) (finding that $40 \%$ of a sample of companies reported reducing their volatility assumptions in the wake of mandated option expense recognition in 2004 (versus $9 \%$ of firms that reported increasing volatility assumptions)). Other studies document unintentional errors in stock option valuation and reporting. See, e.g., Bratten et al., The Accuracy of Disclosures for Complex Estimates: Evidence From Reported Stock Option Fair Values, 52 ACCOUnTING, ORGANIZATIONS AND SOCIETY 32, 34-35.

Accounting commentators have long recognized the manipulability of compensation cost based on the grant date valuation of options. See Balsam, supra note 104, at 36 (preferring exercise date measurement for option compensation as being objective and verifiable); Lauren A. Maines et al., Evaluation of the IASB's Proposed Accounting and Disclosure Requirements for Share-Based Payment, 18 ACCT. HoRIzONS 65, 66, 70 (2004) (noting manipulation concern with cost estimates that are not trued up to actual results); Ohlson \& Penman, supra note 99, at 19 (noting that the lack of cash exchange for compensatory options "raises the specter" of "manipulation opportunities"). 
To some extent, however, disclosure rules limit the ability of firms to manipulate ex ante option values by opportunistically selecting assumptions. ${ }^{163}$ As we saw with Chevron, firms disclose their option pricing assumptions and the technology is available for analysts to confirm the results and re-run the analysis under differing assumptions. ${ }^{164}$ If I think that Chevron's assumption of $30 \%$ volatility is too conservative, I can re-run the numbers with, say, $35 \%$ volatility and see how much this would increase the estimated ex ante value of the options. 165

The opportunities to select favorable assumptions in valuing performance share plans would seem to be even greater. As noted, plans that incorporate shareprice based metrics are accounted for just like options. BBCK analyzed a sample of performance share grants incorporating absolute share-price metrics and found some error, but little bias, in company valuations. ${ }^{166} \mathrm{But}$, as we have seen, plans incorporating relative share price metrics, such as relative total shareholder return plans, involve even more complex and obscure assumptions regarding price correlations. ${ }^{167}$ Even if these assumptions were fully disclosed, it would be more difficult for outside analysts to confirm reported values or compare alternative scenarios. As a result, firms are less likely to be called out for making modeling assumptions that reduce the ex ante value of these grants.

As a side note, although I'm not sure that improved disclosure of assumptions would matter much given the inherent complexity of these instruments, it is not clear whether the paucity of disclosure with respect to performance share plans with a market condition, e.g., Chevron's disclosure quoted above, reflects a lack of guidance from the FASB or SEC or failure of firms to follow such guidance. The FASB requires the disclosure of significant assumptions used in estimating the fair value of share price based awards, including, if applicable,

\footnotetext{
163 ASC 718 requires disclosure in a firm's financial statements of "the significant assumptions used during the year to estimate the fair value (or calculated value) of sharebased compensation awards, including (if applicable)" expected term, expected volatility, expected dividends, and the risk-free rate. Fin. Accounting STANDARDS BD., Accounting STANDARDS CODIFICATION 718-10-50-2(f) [hereinafter ASC 718-10-50-2(f)]. This disclosure requirement applies to all grants of equity pay awards. In addition, SEC regulations require disclosure of the assumptions made in valuing stock and option awards made to the most senior company executives whose compensation is detailed in the summary compensation tables of company proxy statements. 17 C.F.R. §229.402(c)(2) (2015).

164 Supra text accompanying notes 145-148.

$16517 \%$, as it turns out. Ex ante option value is highly sensitive to volatility. See Maines et al., supra note 163, at 70 (noting option valuation sensitivity to assumptions regarding volatility and dividend yields).

166 BBCK (2016), supra note 44, at 59 (Table 5) (finding for a sample of awards incorporating only an absolute stock price metric that company valuations were $13 \%$ lower, on average, than BBCK's risk-adjusted valuations, but were $14 \%$ greater based on medians). 167 Supra text accompanying note 119.
} 
estimated volatility, interest rates, etc. 168 Like other firms that have issued relative total shareholder return awards, Chevron does not disclose specific assumptions such as these with respect to these grants. Although disclosure of assumptions may not be sufficient to replicate Chevron's valuation, it is not clear why disclosure is not required under GAAP.

The valuation reporting issues are slightly different with respect to performance shares with performance conditions (e.g., accounting metrics). As we have seen, if an award is subject only to a performance condition, such as a range of earnings per share targets associated with increasing share awards, an issuer is directed to determine the number of shares that is (most) probable to vest at the time of grant and periodically afterwards. ${ }^{169}$ The reported ex ante value is simply the product of the number of shares probable to vest and the grant date share price. ${ }^{170}$ Over time, the number of shares probable to vest may vary, but the share price is held steady at the grant date price. ${ }^{171}$ Of course, the grant date share price is perfectly transparent for a public company, but the number of shares "probable to vest" is a complete black box. Typically, the target number of shares for an award is also the number deemed most probable to vest at grant. ${ }^{172}$ This means, of course, that the corresponding performance target, e.g., $50^{\text {th }}$ percentile earnings per share performance, is deemed by the board to be the most probable outcome over the performance period.

Firms are not required to disclose and do not disclose how they determine the most probable scenario for these awards. A firm that wished to minimize ex ante valuation for these instruments would select a relatively low level of performance achievement and associated shares as being the most probable result at the time of grant. This determination has no bearing on the design or outcome of the performance plan. If actual performance far exceeds the level deemed most probable at grant, that can be chalked up to effective management.

However, there may be a check on companies minimizing reported compensation in this fashion. Suppose a board believes that $50^{\text {th }}$ percentile growth in earnings per share is the most likely outcome over the performance period, but is

${ }^{168}$ ASC 718-10-50-2(f), supra note 163. See Alexander Merz, Expensing Performance-Based Executive Stock Options: Is There Underreporting Under IFRS 2? 30-31 (Working Paper, Sept. 2015), available at http://ssrn.com/abstract=2603726 (finding significant failure among German listed firms to provide mandated disclosure of performance-vested stock option valuation assumptions and data).

${ }^{169}$ Supra text accompanying note 74.

170 Supra text accompanying note 75.

171 Supra text accompanying note 76.

172 For example, the Coca-Cola Company has issued performance shares utilizing an economic profit growth metric, a performance condition. The disclosed grant date value of these awards is the product of the share price at grant and the number of shares that vest if target performance is achieved. See The Coca-Cola Company, 2014 Proxy Statement (Form DEF 14-A) (Apr. 3, 2014) 63, 68. 
considering reporting grant date valuation based on "most likely" performance of $40^{\text {th }}$ percentile earnings per share growth. Doing so would reduce the number of shares probable to vest and the reported level of executive pay, but it also might send a pessimistic signal to the market that the board would prefer to avoid. ${ }^{173}$

Given current technology, a certain amount of under-reporting of the ex ante valuation of ever more popular performance share awards is probably unavoidable. It is important that we provide investors with an annual, ex ante picture of senior executive pay on as consistent a basis as possible. ${ }^{174}$ Thus, firms must be required to compute ex ante values using models where possible and to base ex ante values on the most probable number of shares to vest, when modeling is beyond our ability. We can improve disclosure requirements, but we can't expect to eliminate under-reporting of ex ante compensation value.

But we do not have to base firm-wide expense for compensation cost arising from these instruments on these highly manipulable estimates. Compensation cost can be tied to much less manipulable realized gains using mark-to-market accounting. Doing so, as suggested above, would reduce the incentive to underreport in the first place. Doing so would also help level the playing the field between the various equity pay instruments that are on the menu at most public companies. It is unclear, for example, why conventional stock options have long dominated economically equivalent cash-settled SAR plans. One possibility is that the mark-tomarket accounting treatment applied to SARs creates undesirable uncertainty with respect to compensation cost. But another possibility is that under current GAAP firms can reduce the compensation cost associated with options (as well as reducing reported executive pay), by selecting favorable valuation assumptions, but they cannot do so with respect to SARs that are marked to market. The growing popularity of performance share plans could also reflect, in part, the opportunity to minimize compensation expense under current accounting rules. Subsection 5 below will argue that avoiding accounting-induced compensation design choices provides yet further justification for shifting to realization-based accounting for all forms of equity pay. Before turning to that analysis, however, let us consider another potential check on valuation manipulation - book/tax conformity.

173 I say "might" send a negative signal because it is not clear that this signal would be observed under current mandated disclosures. Most plans of this type include threshold, target, and maximum performance levels and associated share grants, with interpolation in between these thresholds. Typically, firms use the target level of shares as most probable to vest at grant, but there is no requirement that they do so. A firm could adopt an aggressive target, sending a positive message to investors, all the while assigning a less aggressive level of performance as being most probable at the time of grant. Even if disclosed, it is not clear to me that this would be picked up by many analysts.

${ }^{174}$ As suggested supra note 29, disclosure of aggregate ex ante compensation highlights board decision-making with respect to pay and facilitates cross-company comparison. 


\section{Improving Book/Tax Conformity}

When possible, managers generally prefer to report high income to their investors (by increasing reported income and/or reducing reported expenses) and low income to the tax authorities (by reducing reported income and/or increasing deductions). 175 From a regulatory perspective, the attraction of conforming the recognition rules for financial or "book" accounting and tax is that when the rules are the same, the two spheres provide a natural check on gaming by managers. ${ }^{176}$ The benefit of book/tax conformity is that it forces executives to choose. They may be able to select a treatment that will increase income or decrease it, but not at the same time, for the same transaction. ${ }^{177}$ Given unavoidable executive discretion with respect to reporting, book/tax conformity is an elegant check on the tendency to have it both ways. ${ }^{178}$ Full mark-to-market accounting improves book/tax conformity for equity compensation, which is a strong point in its favor. ${ }^{179}$

With a few relatively unimportant exceptions, the corporate income tax deduction for equity compensation occurs at the point at which the employee realizes her gains, and the deduction is set equal to the amount of those gains. ${ }^{180}$ As we have seen, the book expense for options and performance shares is determined fully or partially at grant and is not trued up to reflect the realized gains of employees. The result is a permanent difference between book expense and tax deductions for these equity pay instruments. In a rising market, tax deductions for equity pay will permanently exceed the compensation cost reported to investors, ${ }^{181}$

\footnotetext{
175 SCHOLES ET AL., supra note 129, at 141.

176 David I. Walker \& Victor Fleischer, Book/Tax Conformity and Equity Compensation, 62 TAX L. REV. 399, 401 (2008-09).

177 Walker \& Fleischer, supra note 176, at 400.

178 Walker \& Fleischer, supra note 176, at 401.

179 Walker \& Fleischer, supra note 176, at 438.

180 Incentive stock options (ISOs) represent one exception to this rule. Under IRC 421 and 422 , employees are taxed not at exercise but on the sale of shares underlying ISOs, and the entire profit is taxed at capital gains rates. However, employers are not allowed a deduction at any time for ISO grants. ISOs should be relatively more attractive at firms that have low effective tax rates, but the tax code limits the value of ISO shares that can be granted to an employee, and thus the large majority of options issued to public company executives, at least, are not ISOs. I.R.C. 422(d) (2012); SCHOLES ET AL., supra note 129, at 191-92 (discussing tax treatment of ISOs); David I. Walker, Is Equity Compensation Tax Advantaged?, 74 B.U. L. REV. 695, 703 (2004) (explaining ISO limitations).

Another exception is restricted stock grants subject to an IRC section 83(b) election. When employees make that election, they are taxed on the value of the stock at grant, not when the stock vests. I.R.C. $\S 83(\mathrm{~b})$ elections are rarely made by employees of public companies but are not infrequently encountered at start-up companies. Id. at 707.

${ }^{181}$ Senator Carl Levin of Michigan has highlighted the discrepancy between corporate tax deductions for options and their book expense and, on several occasions, proposed legislation to limit tax deductions to the amount expensed. See, e.g., Ending Corporate Tax Favors for Stock Options Act, S. 2116, 110th Cong. (2007); Ending Excessive Corporate Deductions for Stock Options Act, S. 1375, 112th Cong. (2011).
} 
and, as or more importantly, underreporting of equity pay book expense has no impact on tax deductions. There is no tax check.

Full mark-to-market accounting for equity pay would true up book compensation cost to the realized gains of the employees, thus ultimately achieving book/tax conformity at the "tax" end of the spectrum. ${ }^{182}$ To be sure, a timing difference would remain. Tax deductions are taken at realization, while book expense is recorded over the life of the equity instrument, but this timing difference is relatively unimportant compared with the current permanent difference. Elimination of the permanent difference would result in a single figure being reported for tax and aggregate book expense for equity pay and in the desired tension between book and tax expense.

\section{Avoiding Accounting Driven Design Choices}

From a corporate governance perspective, the ideal set of accounting (and tax) rules would have no influence on compensation design decisions. Compensation committees and boards would design pay packages for managers that optimize incentives, taking into account the competitive environment, managerial risk aversion, etc., but ignoring accounting (and tax) considerations. While there is still some debate as to whether equity compensation is tax advantaged versus cash, 183 the tax treatment of various forms of equity pay - stock, options, SARs, performance shares - is relatively consistent today. ${ }^{184}$ But there are differences in accounting treatments - differences that have been magnified by the

182 Walker \& Fleischer, supra note 176 , at 436.

183 Compare Walker, supra note 180, at 755-57 (2004) (concluding that equity compensation can produce a combined tax advantage (versus cash) for taxable firms and their employees if the firms properly hedge the grants, but finding little empirical evidence that firms do so) and Michael S. Knoll, The Tax Efficiency of Stock-Based Compensation, 103 TAX Notes 203, 214 (Apr. 12, 2004) (finding that equity compensation is tax advantaged "over a range of circumstances") with Daniel Halperin, 2009 Erwin N. Griswold Lecture Before the American College of Tax Counsel: Rethinking the Advantage of Tax Deferral, 62 TAX LAWYER 535, 541-42 (2009) (suggesting that equity compensation is tax advantaged even if employer and employee face the same marginal rate because equity based returns are normally taxed to both corporation and shareholder but these returns are not taxed to the employee-recipient of equity pay).

${ }^{184}$ Under regular tax principles, employees include gains as ordinary income and employers are entitled to equivalent deductions on the vesting of restricted stock and the exercise of non-qualified options (and SARs). See Walker \& Fleischer, supra note 176, at 405-06. Incentive stock options are subject to a special regime, but are economically much less significant than NQSOs. See infra note 180. These basic rules can be complicated by employee elections under IRC section 83(b); by IRC section 162(m), which limits the deductibility of non-performance based compensation delivered to certain senior executives; and by IRC section 409A, which addresses non-qualified deferred compensation but can reach equity pay in certain circumstances. See Walker \& Fleischer, supra note 176, at 405-06. 
increasing adoption of performance shares plans - that may be distorting compensation design choices. Adopting full mark-to-market accounting for equity pay would not eliminate these distortions, but it would minimize them.

The situation could be, and has been, worse. As we have seen, prior to 2004, stock options were subjected to a uniquely favorable accounting regime. ${ }^{185}$ While all other forms of pay resulted in an expense being recorded for compensation cost, option pay only had to be footnoted. ${ }^{186}$ Kevin Murphy has argued that this favorable accounting treatment contributed to the explosion in option use in the 1990s and early 2000s. ${ }^{187}$ This seems likely. Certainly, option use has declined precipitously following the FASB's adoption of the current option accounting rules in 2004, although, to be sure, other factors have undoubtedly played a role in the shift away from options. ${ }^{188}$

Today, we do not have a situation in which one equity pay instrument is a "free good" from an accounting perspective while others must be expensed. The differences are subtler, but they are likely to distort design decisions, nonetheless. Some of these distortions are troubling; others less so.

Consider first the difference in accounting for economically equivalent stock options and cash-settled SARs. Option expense is based on a calculation of grant date fair value. As we have seen, companies have discretion to select modeling assumptions that reduce compensation cost associated with conventional options, and there is evidence that firms do so. Cash-settled SARs are marked to market, eliminating company discretion over compensation cost and introducing uncertainty into the ultimate charge against earnings (even if this serves an earnings-smoothing function). ${ }^{189}$

Companies, apparently, prefer the stock option regime. Only a small fraction of large U.S. public companies report issuing SARs. ${ }^{190}$ Presumably, this preference is accounting driven, as there are no other meaningful differences between the instruments aside from, perhaps, the relative obscurity of SARs. ${ }^{191}$

185 Supra text accompanying notes 34-36

186 See, e.g., Murphy, supra note 1, at 279-82.

187 See, e.g., Murphy, supra note 1, at 279-82. As noted supra text accompanying note 35, accounting rules are unlikely to have been the sole factor in the option boom. In particular, it seems likely that I.R.C. section $162(\mathrm{~m})$ played a role.

188 Walker, supra note 1, at 615-17; Walker, supra note 41, at 12-14.

${ }^{189}$ Supra text accompanying note 130.

190 Supra text accompanying note 54.

${ }^{191}$ As noted supra text accompanying note 49, there are no tax differences between conventional nonqualified stock options and SARs. The relative obscurity of SARs might suggest path dependence, but performance share plans were relatively unfamiliar ten years ago and are now dominant. Path dependence can only explain so much.

Note also that the difference in accounting for stock options and SARs has little or nothing to do with disclosure. The ex ante and realized values of options and SARs issued to senior 
An accounting-driven difference in the use of two economically similar instruments would seem to be troubling on the surface, but in fact, these two instruments are so economically similar that there is little or no efficiency loss if SARs are effectively removed from the compensation smorgasbord. ${ }^{192}$ The only difference between them is that options result in shares being issued, while cashsettled SARs do not. But the FASB has decided that conventional options can be effectively cash settled through the use of "cashless" exercise schemes, without adversely affecting the option accounting treatment, so even that difference turns out to be insignificant. ${ }^{193}$

But now consider the differences in accounting treatment of performance share plans with share-price based metrics and accounting-based metrics. The former are accounted for based on a calculation of grant date fair value, just like options, but arguably with greater discretion to select modeling assumptions that minimize reported compensation expense. ${ }^{194}$ The latter are partially marked-tomarket (share price fixed; number of shares most probable to vest adjusted periodically and tied to actual), eliminating company discretion over compensation cost and adding uncertainty as to the ultimate expense booked, but providing significant discretion over the reported grant date value of awards made to senior executives. ${ }^{195}$

It is not obvious which of these regimes would be preferred from an accounting perspective. ${ }^{196}$ BBCK report data suggesting a shift towards incorporation of accounting-based metrics. ${ }^{197}$ Different firms may have different

executives are fully disclosed in company proxy statements. 17 C.F.R. $§ 229.402$ (2015). The real difference lies in the adjustment to earnings with respect to the instruments.

192 Commentators have long recognized and criticized the significant differences in accounting treatment of stock options and economically equivalent cash-settled SARs. However, they have not recognized that the resulting distortion likely has little or no efficiency cost in this particular situation. See Balsam, supra note 104, at 56 (noting "the incentive to design plans 'around accounting standards'”); Maines et al., supra note 162, at 66 (noting that focus on form over substance leads to "transaction structuring to meet reporting goals"); Ohlson \& Penman, supra note 99, at 12 ("ad hoc accounting rules facilitate the issuance of form-over-substance claims designed to achieve a desired accounting result"). To be sure, each of these commentators has additional arguments for reforming the accounting treatment of options, which at the time constituted the primary equity compensation vehicle.

193 Supra note 101.

194 Supra text accompanying notes 166-167.

195 Supra text accompanying notes 169-173.

196 Note that if valuation assumptions are unbiased, the expected compensation expense would be the same under grant date valuation or partial mark-to-market accounting, but as we have seen different methods provide differing opportunities for manipulation, and greater or lesser uncertainty with respect to compensation cost.

197 BBCK (2016), supra note 44, at 39-40. 
views. The point is that these are significant differences in accounting treatments that may distort compensation plan design. Moreover, assuming one takes incentives at all seriously, it matters whether performance targets are based on share-price metrics, such as total shareholder return, or accounting-based metrics, such as earnings per share. These are not interchangeable the way that options and SARs are interchangeable. Incentives do matter, sometimes too much. If you compensate a manager based on growth in earnings per share, she will tend to focus excessively on growth in earnings per share. ${ }^{198}$ Companies need to be deliberate in the selection of plan metrics and accounting driven distortions can interfere with efficient design.

To be sure, firms can adopt multiple metrics. Firms can take advantage of the partial mark-to-market accounting regime, if they so choose, by adding an accounting-based metric to a plan that already incorporates one or more shareprice based metrics. It need not be an either/or proposition. But adding metrics primarily to achieve accounting ends is suboptimal as well. Additional metrics may distract managers from their primary mission. ${ }^{199}$

Consistency in the accounting treatment for equity pay can be best achieved at the full mark-to-market end of the spectrum, by basing compensation cost on realized equity pay proceeds. ${ }^{200}$ Even then, adopting mark-to-market accounting would not completely level the accounting playing field.

The most economically significant equity pay instruments currently in use are performance shares, options, and time-vested RS/RSUs. It is feasible (even if arguably unwise) to base compensation expense for each of these on a measure of grant date fair value, except for performance shares with non-share price based metrics. As noted above, the FASB has concluded that we lack the technology currently to adequately value the latter at grant.201

With its emphasis on grant date share price and estimating the number of shares that is most probable to vest, the partial mark-to-market approach that FASB has adopted for performance shares utilizing accounting-based metrics is only suitable for variable share awards. For time-vested restricted stock, application of

198 PaUl Milgrom \& John Roberts, Economics, ORganization And Management 240 (noting that when an employees time allocations and effort cannot be observed, "[p]roviding strong incentives for a portion of an employee's activities can cause the employee to cut back his or her effort in other activities").

199 MILGROM \& ROBERTS, supra note 198, at 240.

200 As noted supra notes 32-37, it appears that earnings matter to corporate decision makers independent of cash flows and that disclosure is not a perfect substitute for incorporating accounting information in earnings. As such, consistent earnings adjustments are needed to level the accounting playing field for equity pay, not just consistent disclosure via footnotes to financial statements.

201 Supra text accompanying note 155. 
the partial mark-to-market approach would be trivial; it would be the same as the current grant date fair value approach. For options, the partial mark-to-market approach simply makes no sense. If one locks in the share price at the time of grant for an at-the-money option, the option would never be in the money and there would never be any compensation cost to record.

Each of these equity instruments can be accounted for on a full mark-tomarket basis. Although it is unusual, we already do so when options take the form of cash-settled SARs. This approach could easily be applied to all options. It could also easily be applied to all performance share plans. The only difference between full mark-to-market and partial mark-to-market, is that the share price floats as well as the number of shares probable to vest. The approach can also be applied to time vested RS/RSUs. Rather than booking the share price at grant, we would book the share price at vesting, and adjust for fluctuations between grant and vesting.

Full mark-to-market or realization-based accounting is feasible for all types of equity pay and would level the playing field with respect to accounting for compensation cost firm-wide. ${ }^{202}$ To be sure, proxy statement disclosure of the grant date value of executive pay would be unaffected. We would still need to use models or estimates for options and performance shares to generate this information. And the opportunity to minimize reported executive pay would undoubtedly affect the choice of pay instrument at some companies. Nonetheless, realization-based accounting for equity pay would eliminate the influence of accounting on compensation design along one important dimension, and this provides another rationale for embracing full mark-to-market accounting as the general rule for equity pay.

\section{Timing Differences}

Thus far we have focused primarily on determining the amount of compensation cost booked as an expense and less on the timing of the entries. In the world of tax, timing is critical. ${ }^{203}$ Deferring the payment of a fixed amount of tax reduces the present value of the obligation. ${ }^{204}$ But financial accounting is quite

202 While consistent application of realization-based accounting to equity-based and other long-term pay would eliminate inconsistencies in accounting between these instruments, it would sharpen the accounting contrast between annual salary and bonus (expensed at cash value in the year of grant) and long-term compensation (marked to market). As a result, some firms might marginally increase their emphasis on the former at the expense of the latter. In my view, however, this is less of a concern than is the current inconsistency in accounting for various long-term compensation devices.

203 Daniel I. Halperin, Interest in Disguise: Taxing the Time Value of Money, 95 YALE L.J. 506 (1986).

${ }^{204}$ At least in the case of pure deferral, such as an option to immediately deduct an expense that would normally be capitalized. Daniel I. Halperin \& Alvin C. Warren, Jr., Understanding Income Tax Deferral, 67 TAX L. REV. 317 (2014) (distinguishing "pure deferral," which is 
different. Often there are no cash flow consequences from accelerating book income recognition or deferring it. But this does not mean that managers aren't concerned about the timing of accounting income or deductions. Not only do managers prefer to report greater income to investors rather than lesser; they prefer to report greater income now and lesser income later, if given the option to do so. ${ }^{205}$

Nonetheless, differences in the timing of compensation cost recognition associated with various equity pay instruments would seem to be a second order concern. With the exception of options and SARs, compensation cost would be recognized ratably across the vesting or performance period for all forms of equity pay under all methods. For example, under current rules, the calculated ex ante value of performance shares incorporating only share-price based metrics is recognized ratably over the performance period. If these instruments were marked to market, the expense would still be recognized over the performance period, although the amount recognized each year would vary with market movements, as one would expect with marking to market. In either case, grant date valuation would be based on a model, providing equal latitude for minimizing the proxy statement reported value of any performance shares granted to senior executives. ${ }^{206}$

Similarly, the compensation cost for performance shares incorporating accounting-based metrics would be recognized across the performance period under either the current partial mark-to-market system or a full mark-to-market system. And again, the two methods provide equal discretion with respect to grant date valuation/reporting of senior executive compensation. ${ }^{207}$

There is a difference in the timing of expense recognition for options and SARs depending on whether they are accounted for based on grant date fair value or are marked to market. Options and SARs typically vest between one and five years following grant, and are expensed ratably over the same period under grant date fair value accounting. ${ }^{208}$ Under a mark-to-market approach, the expense for options or SARs continues to be adjusted post-vesting until the instruments are exercised or

equivalent to an interest-free loan from the government, from "counterparty deferral," the tax advantage of which depends on the parties' tax rates).

205 SCHOLES ET AL., supra note 129 , at 141.

206 This does not imply that first year expense recognition would be identical under the two schemes. It would not. Currently, the value of a performance share award with a market metric is measured at grant, once and for all, and is recognized ratably over the performance period. Under the mark-to-market approach that currently applies to cashsettled SARs, the expense for the first year would be determined, using a model, at the end of that year.

${ }^{207}$ Recall that grant date reporting of compensation is only relevant for the "top 5" executives of public companies. See supra text accompanying note 29. Outside this rarefied group, the only issue is the amount of compensation expense recognized with respect to equity pay.

208 Supra text accompanying notes 43-47. 
expire unexercised, which can be up to ten years following grant. ${ }^{209}$ On average, options that are in the money are exercised about five to six years following grant. ${ }^{210}$ In any event, under a mark-to-market approach, the period of expense recognition for options/SARs would be longer than it is under grant date fair value accounting. However, the post-vesting adjustments to compensation cost and earnings may be positive or negative. There is no reason to expect a bias. Aside from a distaste for uncertainty, the extended recognition period for options under a full mark-to-market regime would not seem to be a major negative.

\section{Additional Arguments Against Realization-Based Accounting for Equity Pay}

In the previous sections, I have attempted to provide a balanced view of the arguments in favor of realization-based accounting for equity pay, as well as the related counter-arguments or limitations. However, there are several counterarguments that deserve separate consideration. This section will briefly consider these functional arguments, setting aside "is it equity or a liability?"-type debates.

\section{Mark-to-Market or Realization-Based Accounting Introduces Unnecessary Noise into Reported Compensation Expense}

One can certainly argue that to the extent that equity pay realizations reflect broad market movements, or perhaps even a random walk, incorporating these results in compensation cost introduces noise that reduces the comparability of results from firm to firm and over time. This much is true, but this is really just the flip-side of the arguments made in Part III.B.2 above. The question is whether increases or decreases in compensation post-grant should be thought of as noise or as useful information. Even realized retail sales commissions reflect some market noise.

I argued in Part III.B. 2 above that the rise of performance share plans means that pay is now more closely tied to performance, mitigating the noise concern, but some noise remains. The relevant questions are whether including post-grant price movements in compensation cost increases the usefulness of the information and,

\footnotetext{
${ }^{209}$ Supra text accompanying note 53. Kaplan \& Palepu argue that mark-to-market accounting should cease at vesting because at that point the employee "becomes just another equity holder." Kaplan \& Palepu, supra note 117. But vested employee stock options remain nontransferable and are not equivalent to market traded options. As a result, valuation at vesting would still be based on a model and would require assumptions on early exercise dates, raising manipulation concerns. Moreover, absent a change in tax rules, book/tax conformity is not achieved unless marking to market continues to exercise. On balance, it seems sensible to continue to mark options and SARs to market until the instruments are exercised or expire.

210 Supra note 139.
} 
even if it does not, whether some additional noise is an acceptable price to pay for the other benefits of realization-based accounting - limiting manipulation of compensation cost, minimizing accounting-based distortions in pay design, and achieving book/tax conformity.

\section{Realization-Based Accounting Creates an Unacceptable Level of Uncertainty in Compensation Cost}

With grant date-based accounting, compensation cost arising from a stock option is fixed and certain at the time of grant. With realization-based accounting, the ultimate expense is uncertain. Mark-to-market compensation cost for an option could rise sharply in a bull market. This uncertainty could be viewed as a drawback to realization-based accounting for compensation cost. ${ }^{211}$ Compensation expense uncertainty is the flip-side of the earnings-smoothing benefit of mark-to-market discussed in Part III.B.2 above, but the concern would be that the cost of uncertainty may outweigh the earnings-smoothing benefit.

We should first observe that the uncertainty here is a real economic phenomenon. If the accounting is uncertain, it is only because the underlying obligation is uncertain. A firm that issues a stock option is committed to deliver shares to the employee at exercise. The employee pays a fixed, pre-determined price for the shares. The shares delivered may be worth several multiples of the exercise price or the option may expire unexercised and worthless. The opportunity cost at exercise is highly uncertain at grant.

Of course, firms can do something about the underlying economic uncertainty and the resulting accounting uncertainty under a realization-based approach. The payoff on an option or an SAR can be capped. ${ }^{212}$ The time frame for exercise or payout can be constricted, reducing, but not eliminating, uncertainty in both actual and reported compensation cost. ${ }^{213}$ It may also be possible for firms to

${ }^{211}$ Commentators frequently note the unattractiveness of mark-to-market or "variable accounting," as this approach was labeled under APB 25. However, it generally is not clear whether the primary concern with mark-to-market accounting is uncertainty, volatility (discussed in the following subsection), or simply the administrative cost of periodic calculation of the equity compensation valuations. See, e.g., Mark E. Bokert, Understanding the New Accounting Rules for Stock Options and Other Awards, 13(7) The Metropolitan CORPORATE COUNSEL (July 2005), available at http://www.dglaw.com/images_user/newsalerts/MCCJuly05Bokert.pdf (noting that "SARs are subject to variable accounting. For this reason, not many companies use SARs.").

212 Urban Outfitters, for example, has issued SARs to executives with payouts capped at $500 \%$ of the grant date fair value of the awards. See Urban OUTFITTERS, InC., 2011 ProxY STATEMENT (FORM DEF 14A) 32, (Apr. 1, 2011).

213 The shift in emphasis away from options and in favor of performance shares has already had this effect. Stock options typically expire ten years following grant. While in-the-money options generally are exercised well prior to expiration, the potential exists for 10 years of 
hedge equity pay arrangements by purchasing shares of their own stock on the market that they can then deliver to their employees (or sell back into the market) when an equity pay award is exercised or settled. ${ }^{214}$

\section{Realization-Based Accounting Creates an Unacceptable Level of Volatility in Compensation Cost}

A related concern is that realization-based accounting introduces an unacceptable level of volatility into compensation cost reporting, and, if significant enough, earnings. ${ }^{215}$ This may be a valid concern, but as several commentators have proposed, the concern can be addressed by smoothing the adjustment of earnings for compensation cost. ${ }^{216}$ Note that this smoothing is not equivalent to grant datebased accounting. Ultimately, realized compensation cost would be fully reflected in earnings under a smoothed mark-to-market approach.

To isolate the volatility issue, suppose a firm makes an option or SAR grant to an executive that vests in three years and expires in ten years. Suppose the grant date BSM value is $\$ 3$ million. If the instrument is an option, the current accounting treatment would require the firm to ratably expense the grant date value over the three year life resulting in an expense of \$1 million per year for three years.

Suppose instead that the instrument is an SAR and that at the end of the first year the BSM value of the instrument is $\$ 4.5$ million (due to an increase in stock price, volatility, and/or projected dividend yield over that first year). The first year expense would be $1 / 3$ of this amount or $\$ 1.5$ million. Assume at the end of year two that the recalculated BSM value is $\$ 6$ million. Because service has been provided for two years, the cumulative expense that must be recognized is $\$ 4$ million. Thus, the second year expense would be $\$ 2.5$ million ( $\$ 4$ million minus $\$ 1.5$ million). Now suppose the market heads south and the BSM value at the end of year three falls back to $\$ 3$ million. The option has now vested and cumulative expense must equal $\$ 3$ million, requiring a negative adjustment to compensation cost in year three of $\$ 1$ million.

appreciation. Performance share plans are typically based on a three-year performance period, reducing the scope for massive escalation in share value between grant and payout. ${ }^{214}$ Hedging can certainly be used to minimize the underlying economic uncertainty of equity grants. An adjustment in accounting for hedging transactions may be needed to enable firms to hedge the uncertainty in compensation cost for net income that is associated with mark-to-market accounting. Hedge accounting is briefly discussed in Part IV below.

${ }^{215}$ See, e.g., G. Edgar Adkins, FAS 123(R) - Avoiding the Unexpected, at 6, GranT THORNTON, available at http://www.grantthornton.com/ /media/content-page-files/tax/pdfs/whitepapers-survey-reports-articles/2013/FAS-123R-avoiding-the-unexpected.ashx (noting that liability awards may result in income statement volatility).

216 Infra text accompanying note 220. 
In both cases, aggregate compensation cost recognized over the three years is $\$ 3$ million, but the option results in ratable recognition, while the SAR results in volatile stream of compensation cost of $\$ 1.5$ million, $\$ 2.5$ million, and $-\$ 1$ million. I have, to be sure, concocted an example in which option treatment gets to the "right" result and produces much less volatility in compensation cost recognition, ${ }^{217}$ but the volatility issue is a real concern even if one has a clear preference for realizationbased accounting over grant date fair value-based accounting.

While some proponents of realization-based accounting for equity pay support adjusting compensation cost and net income in each period for changes in valuation occurring during that period 218 - the current SAR approach - others suggest smoothing the incorporation of compensation cost adjustments into net income. As Professors Kirschenheiter, Mathur, and Thomas (KMT) note, mark-tomarket accounting should, in principle, reduce earnings volatility - the earningssmoothing function - but it can increase volatility when compensation cost adjustments are concentrated in a single year while broader earnings impacts are spread over several years. ${ }^{219}$ Given that possibility, KMT suggest that annual changes in option values be "'smoothed' over future years' earnings;" recorded as "other comprehensive income" (OCI), an account used to record certain gains and losses that do not directly impact the key net income or earnings figure; ${ }^{220}$ or disclosed in footnotes. ${ }^{221}$ Professors Ohlson and Penman go a step further, explicitly proposing that the mark-to-market adjustments be initially recorded as OCI, but "gradually pass through the Income Statement," such that these gains and losses "would thereby be 'smoothed' over many periods into Net Income." 222 Ohlson and Penman find this ultimate truing up to be an "attractive feature" of this approach as it both recognizes the true economic cost of equity pay to shareholders and minimizes the incentives to under-report executive pay. ${ }^{223}$

217 Obviously here I am designating the mark-to-market/realization-based approach as the "right" result. Note, however, that while option and SAR accounting have converged at the end of year three in this example, there is no guarantee that the final compensation cost will converge. Option accounting ends with vesting. SAR mark-to-market accounting continues until exercise or expiration.

218 Maines et al., supra note 162 , at 74.

${ }^{219}$ Kirschenheiter et al., supra note 104 , at 154.

220 J. DAVID SPICELAND ET AL., InTERmediate ACCOUnTing 194 (6th ed. 2011). Gains or losses from foreign currency translation are an example of an income item that bypasses net income but is included in OCI. Id.

${ }^{221}$ Kirschenheiter et al., supra note 104, at 155. Kirschenheiter, Mathur, and Thomas do not take a position on which of these approaches to reporting mark-to-market compensation cost adjustments would be superior.

222 Ohlson \& Penman, supra note 99, at 24. Ohlson and Penman prefer to initially separate what they term "windfall gains and losses" arising from mark-to-market accounting for equity pay from net income by running these gains and losses through OCI because, in their view, analysts will wish to separate these adjustments from ' core' or 'recurring' Net Income." Id. at 18.

223 Ohlson \& Penman, supra note 99, at 21, 22. 
To be clear, the Ohlson and Penman approach simply smoothes the incorporation of mark-to-market adjustments for equity pay into net income, addressing the volatility concern, but maintaining the ultimate link between aggregate compensation cost recognition and employee realizations from equity pay. While the current accounting for stock options also results in a smooth adjustment to earnings, the similarities between the two approaches ends there.

Also, to be clear, the current liability-based accounting for SARs and for cashsettled performance awards does not smooth mark-to-market adjustments into net income. In each period, net income is adjusted for changes in equity pay valuation that arise in that period. At the end of the day, while I believe the case for reflecting equity pay realizations in net income is strong, I am agnostic whether mark-tomarket adjustments should be recognized as they arise or smoothed into net income. ${ }^{224}$

To be sure, each of the foregoing concerns - the introduction of unnecessary noise, uncertainty, and volatility into earnings - could be alleviated by mandating footnoting of marked-to-market compensation cost rather than requiring firms to incorporate mark-to-market adjustments into their earnings calculations with respect to long-term pay awards classified as equity. While the adoption of a footnoting approach might be viewed as a partial victory, it would likely be a hollow victory from a corporate governance perspective. The U.S. stock option expensing saga demonstrates that firms are much less responsive to footnoting than they are to expensing. ${ }^{225}$ Moreover, as I have argued above, ${ }^{226}$ mark-to-market accounting for equity pay is increasingly appropriate given the evolution of these instruments.

\section{A Note on Hedging Equity Compensation Awards}

At the time of grant, the ultimate payout on equity compensation awards is uncertain. That uncertainty is inherent in a scheme that ties pay to long-term performance, which is unknown at grant. Payouts are uncertain in two respects. First, there is underlying economic uncertainty: What will it cost the firm to deliver the shares or share-based cash at exercise or settlement? Second, there may be

${ }^{224}$ An additional argument for smoothing mark-to-market adjustments into net income is that the volatility issue would be more significant in industries characterized by more volatile stock prices and that, without smoothing, adoption of mark-to-market accounting could be viewed as penalizing companies in those industries.

225 Supra text accompanying notes 186-187.

${ }^{226}$ Supra Part III(B). 
uncertainty regarding the amount of compensation cost ultimately recorded for the pay award: How much will the award reduce earnings?

The evidence is mixed on the degree to which firms hedge equity pay awards. Many firms repurchase shares on a regular basis to manage the dilution that results from regularly issuing shares or options to employees. Whether intended or not, those repurchases may serve to hedge the economic impact of equity awards. ${ }^{227}$

Suppose a firm explicitly hedges an equity pay award. Suppose the firm issues an RSU on a single share that vests in three years and at the same time repurchases a share on the market. The firm has locked in the economic cost of the compensation since the firm can deliver the purchased share to the employee at vesting. This hedge does not impact the incentives of the employee, so the incentive function is maintained without exposing the firm to the risk of a share price run up during the vesting period.

This hedge is effective as an economic matter, but what about as a means of managing uncertainty in reported compensation cost and net income? Under current accounting rules for equity pay, there is no compensation cost uncertainty. The compensation cost for an RSU is not currently marked to market. Compensation cost is set equal to the grant date value of the share and is recovered over the vesting period. ${ }^{228}$ Moreover, the hedge has no impact on net income because gains or losses on transactions by a company in its own shares do not flow through the income statement. They are considered transactions between a firm and its owners. ${ }^{229}$ In sum, when a firm hedges equity awards subject to grant date fair value accounting in order to eliminate economic uncertainty, accounting for the

${ }^{227}$ A number of studies find a relationship between option grants and share repurchases, although the rationales are less certain. See Gene Amromin \& Nellie Liang, Hedging Employee Stock Options, Corporate Taxes, and Debt, 66 NAT. TAX J. 513 (2003) (finding evidence consistent with stock option hedging); Daniel A. Bens et al., Employee Stock Options, EPS Dilution, and Stock Repurchases, 36 J. AccT. \& ECoN. 51, 82, 86 (2003) (concluding that financial reporting considerations, specifically the dilutive effect of options on EPS, explain repurchase decisions); Kathleen M. Kahle, When a Buyback Isn't a Buyback: Open Market Repurchases and Employee Options, 63 J. Fin. Econ. 235 (2002) (earnings dilution); Haim A. Mozes \& Steven B. Raymar, Granting and Hedging Employee Stock Options: A Tax Motivation and Empirical Tests 1 (Working Paper July 24, 2001) (finding evidence consistent with a tax motivation for option related repurchases); Scott J. Weisbenner, Corporate Share Repurchases in the 1990s: What Role Do Stock Options Play? 25 (FEDS Working Paper No. 2000-29, Apr. 2000) (finding evidence consistent with dilution management and executive self-enrichment theories); Daniel A. Rogers, Repurchases, Employee Stock Option Grants, and Hedging 7-15, 17 (Working Paper, Sept. 2006) (finding for a sample of 151 large firms over the decade ending in 2004, median share repurchase equal to $36 \%$ of shares underlying options issued in a given year $\left(0 \%\right.$ at $25^{\text {th }}$ percentile; $158 \%$ at $75^{\text {th }}$ percentile) and finding evidence consistent with a hedging motivation).

228 Supra text accompanying notes 59-61.

229 SPICELAND ET AL., supra note 220, at 1024. 
hedge does not undo the compensation cost certainty that is a hallmark of this approach to accounting for equity compensation.

Now suppose that all equity awards were subject to mark-to-market accounting. Firms issuing these instruments would face both economic and compensation cost/net income uncertainty. Hedging these awards as described above could eliminate the economic uncertainty, but if the hedge is accounted for as just described, the gains and losses on the hedge would not flow through the income statement and would not offset the losses and gains on the equity award that arise from mark-to-market accounting. Under the existing rules, a firm could not hedge the net income impact of equity awards that are marked to market by repurchasing its own shares. ${ }^{230}$ This would be a perverse result. If realization-based accounting were to be adopted as the general approach to equity pay accounting, it would be sensible to permit gains and losses on share repurchases specifically identified as hedging marked-to-market equity awards to flow through the income statement so as to provide an effective economic hedge and net income hedge.

\section{Conclusion}

The U.S. equity compensation landscape continues to evolve. Recent innovations have improved the linkage between pay and firm-specific performance, but have added complexity. Given these changes, and whether considering the matter within the FASB's conceptual framework or as a matter of facilitating good corporate governance, the arguments for adopting realization-based accounting for equity compensation have never been stronger. To me they are persuasive. But rather than recapping the arguments (see the abstract, introduction, or text), let me conclude this Article with a word about accounting for equity pay and politics.

While accounting is not as overtly political as tax, for instance, there is little doubt that political considerations play a role in the standard setting process. The FASB does not adopt standards in a vacuum. And politics have played a particularly visible role in the battles over accounting for equity pay. Numerous bills have been introduced in Congress that would have directed the FASB or SEC to regulate, or refrain from regulating, in this arena. ${ }^{231}$ Although none of these bills passed, the

230 The inability to hedge the income statement impact of SARs might be another reason for the relative unpopularity of these instruments compared with conventional options.

${ }^{231}$ A non-exhaustive list includes the following: the Corporate Executives' Stock Option Accountability Act, introduced by Senator Levin in 1993, which would have directed the SEC to require firms to expense options; the Equity Expansion Act of 1993, introduced by Senator Lieberman, which would have prohibited the SEC from mandating option expensing; the Broad-Based Stock Option Plan Transparency Act, introduced in the House in 2005 and which would have directed the SEC to adopt enhanced disclosure for option compensation, to examine and report to Congress on the effectiveness of those disclosures, 
simple introduction of such legislation must attract the attention of the regulators. The last thing the FASB or the profession needs is for Congress to meddle in accounting standards. But political considerations extend beyond Congress. Accounting is largely a self-regulated profession, and it must be difficult for the regulators to ignore a near consensus among those regulated. It was highly commendable of the FASB to mandate option expensing in the face of overwhelming industry opposition.

I do not purport to know what the members of the FASB were thinking in 2004 when they adopted stock option expensing based on grant-date valuation. But a move from a regime under which option compensation resulted in booking no expense at all to one requiring mark-to-market accounting, raising concerns about volatile and unpredictable earnings, might well have been unattainable. Even if some FASB members thought a realization-based approach to be superior, it might have been perfectly sensible in 2004 to support an achievable grant-date measurement approach.

But a decade has passed. Few would argue today that stock options or any other form of equity pay should not be expensed at all. Thus, while it's certain that a shift to realization-based accounting for equity pay would not be popular with industry, there's little or no risk of a backlash returning us to a pre-SFAS 123R world of "free" options. Moreover, it seems unlikely that a proposal to shift from grantdate to realization-based measurement would attract congressional attention the way the fundamental expensing question did. More likely, most members of Congress and their staffs would view such a change as a tweak.

If so, perhaps the regulatory "space" exists for the FASB to readdress the details of equity pay expensing and, in particular, the grant-date measurement requirement. Perhaps it is best to do so in the context of reassessing the equity/liability characterization of equity pay awards, but, as I have argued, one would hope that functional considerations will ultimately determine the outcome, not formal characterization as an equity instrument or a liability.

to refrain from issuing new option accounting rules in the interim; the Ending Excessive Corporate Deductions for Stock Options Act, introduced by Senator Levin and others in 2009 and other years, which would have, inter alia, limited corporate tax deductions for options to the amount recognized as an expense for financial accounting purposes. 